\title{
Eğitim Fakültesi Son Sınıf Öğrencilerinin Bilişim Güvenliği Farkındalıkları: Sakarya Üniversitesi Eğitim Fakültesi Örneği*
}

\author{
Özcan Erkan AKGÜN**
}

Murat TOPAL ${ }^{* * *}$

Öz

$\mathrm{Bu}$ çalışma eğitim fakültelerinde öğrenim gören öğrencilerin bilişim güvenliği farkındalıklarını incelemek amacıyla gerçekleştirilmiştir. Araştırma tarama modelinde yürütülmüştür. Katılımcı grubu Sakarya Üniversitesi Eğitim Fakültesi son sınıfında okuyan farklı bölümlerden toplam 217 öğrenci oluşturmaktadır. Veri toplama aracı olarak araştırmacılar tarafından geliştirilen “Bilişim Güvenliği Anketi” kullanılmıştır. Veriler betimleyici ve anlam çıkarıcı istatistikler kullanılarak analiz edilmiştir. Araştırma sonuçlarına göre bilişim güvenliği konuları ile ilgili farkındalıklarının yeterli olmadığını belirten azımsanmayacak sayıda öğrenci olduğu görülmüştür. Cinsiyete, ortalama bilgisayar-internet kullanım yılına göre bazı konularda anlamlı farklılıklar olduğu gözlenmekle birlikte, bilişim güvenliği eğitimi aldığını belirten adaylar ile almayan adaylar arasında beklendiği gibi ciddi bir anlamlı farklılık gözlenmemiştir. Öğretmen adayları için kapsamı iyi belirlenmiş bir bilişim güvenliği eğitimi verilmesi önerilmektedir.

Anahtar Kelimeler: Bilişim Teknolojileri, Bilişim Güvenliği, Bilgi Güvenliği, Öğretmen Adayı

\section{Information Security Awareness of the Senior Teacher Students: Sakarya University Sample}

\begin{abstract}
This study was conducted in survey model to determine awareness of information security of the 217 prospective teachers from different departments that attending Faculty of Education at Sakarya University. "Information Security Questionnaire" that developed by authors was used for data collection. The findings of the survey revealed, that there were important number of students at low levels of awareness. There were significant differences in some cases about awareness level of information security between gender, average computer-internet usage experience by year. Contrary to expectations there were no significant difference between prospective teachers that had education about information security and prospective teachers that have no education about information
\end{abstract}

\footnotetext{
${ }^{*}$ Bu çalışma 19 Eylül 2014 tarihinde 8. Uluslararası Bilgisayar ve Öğretim Teknolojileri Sempozyumunda sunulan ve tam metin olarak bildiriler kitapçı̆̆ında yer almayan aynı adlı bildirinin genişletilmiş ve geliştirilmiş halidir.

** Yrd. Doç. Dr, Sakarya Üniversitesi, Bilgisayar ve Öğretim Teknolojileri Eğitimi Bölümü, oakgun@sakarya.edu.tr

*** Arş. Gör., Sakarya Üniversitesi, Bilgisayar ve Öğretim Teknolojileri Eğitimi Bölümü, mtopal@sakarya.edu.tr
} 
security. It is suggested to give inclusive and effective information security education to prospective teachers attending Educational Faculties.

Keywords: Information Technologies, Information Security, Information Security Awareness, Prospective Teachers

\section{GİRIŞ}

Hayatımıza sayısız kolaylık sağlayan bilişim teknolojileri geleneksel birçok uygulama ve hizmetin sunulmasında yer alırken aynı zamanda sağladığı üstünlükler sayesinde de gittikçe vazgeçilmez olmaktadır. Bilişim teknolojilerinden yararlanılan alanların gün geçtikçe artması birçok uygulama ve hizmeti elektronik ortama taşımaktadır. E-devlet, e-ticaret, ebelediye, e-öğrenme ve e-sağlık gibi uygulama ve hizmetler günlük yaşamımızın bir parçası haline gelmiştir (Dedeoğlu, 2006). Diğer yandan bilişim teknolojilerinin hayatımızda yaygın kullanımının artması bu teknolojilerin kolaylıklarının yanında bazı olumsuz yanlarını da beraberinde getirmektedir. Bilişim güvenliği konusu da bunlardan biridir. Bilişim teknolojilerini kullanarak işlemlerin gerçekleştirilmesi, depolama yapılması, iletişim kurulması, dijital ortamlarda bulunan bilginin güvenliğini dolayısı ile bilişim güvenliğini önemli bir hale getirmektedir (Yavuz ve Ulaş, 2013; Çalık ve Çınar, 2009).

Herkes tarafından erişilen bir bilginin güvenli bir biçimde gönderen ve alıcı arasında bütünlüğü bozulmadan, belli bir gizlilik içinde güvenli bir biçimde iletilmesi bilgi güvenliği olarak ifade edilebilir (ISO, 2005; Akt. Vural ve Sağıroğlu, 2008). Bilgi güvenliğinin üç temel unsuru; gizlilik, bütünlük ve kullanılabilirlik olarak ifade edilmektedir (Baykara, Daş ve Karadoğan, 2013). Gizlilik, bilginin yetkisiz erişiminin engellenmesini; bütünlük, bilginin yetkisiz kişilerce tahrip edilmesinin engellenmesini; kullanılabilirlik ise bilginin ihtiyaç olunduğunda erişilebilir olmasıdır (Baykara, Daş ve Karadoğan, 2013; Tekerek, 2008). Bilginin dijital ortamlarda depolandığı, iletildiği ve ulaşıldığı çağımızda bilgi güvenliği kavramı ve bilişim güvenliği kavramı artık içe içe hale geçmiştir.

Bilişim teknolojileri ve özellikle internet yasadişı yollarla diğer bireyler veya kurumlardan faydalanmak isteyen kötü niyetli kişilere şimdiye kadar benzeri görülmemiş olanaklar sağlamaktadır (Mann ve Sutton, 1998). Bilginin rahatlıkla açı hedef haline gelebildiği dijital ortamlarda (Pro-G, 2003) bilişim korsanları bu bilgilerin depolandığı ve kullanıldığı sistemlere zarar verebilmekte, sistemi kullanılmaz hale getirebilmekte ve bilgiler çalınabilmektedir. Bilişim suçu veya siber suç (Siber, 2013) olarak adlandırılabilen bu zararlı faaliyetler Gordon ve Ford'a göre (2006) genel olarak kötü niyetli kişiler tarafından bizzat yönlendirilen veya bu kişiler tarafından bilişim suçu işlemek amacıyla oluşturulmuş programlar kullanılarak kişisel bilgilerin edinilmesine yönelik sistemlerin açıkları ve zayıf yönlerinden yararlanılması ile gerçekleştirilir. Bu zararlı faaliyetlerin bir sonucu olarak kurumsal bilgilerin çalınması ve yasadışı yollarda kullanılması (Thomson ve Solms, 1998), kurum ve organizasyonlar için ekonomik anlamda kayıplar oluşturması (Gordon ve Loeb, 2002) gibi durumlar ortaya ç1karmakla birlikte kişisel kullanıcılar için de bilgilerin gizliliğinin ihlali ve ekonomik maddi kayıplar meydana getirebilmektedir (Cavusoglu, Cavusoglu ve Raghunathan, 2004). Bilişim güvenliğine yeteri kadar önem verilmediği takdirde, özellikle banka/kart bilgilerinin çalınması, telif hakkı ihlalleri, müstehcenlik, çocuk istismarı, kişisel verilerin çalınması ve internetteki yasa dışı yayınlar ülkemizde en sık rastlanan bilişim suçları arasındadır (İlbaş ve Köksal, 2011). Bu tip sorun ve kayıplarla karşı- 
laşmamak için bilgi güvenliği dolayısı ile bilişim güvenliği konusunda önlemler almak, gerekirse kurumsal düzeyde potansiyel risklere karşı politikalar geliştirmek gereklidir (Whitman ve Mattord, 2012).

Türk Ceza Kanunu'nun (TCK) (2014) “Bilişim Alanında Suçlar" bölümünde (Onuncu bölüm) bilişim suçları genel olarak; bir bilişim sistemine hukuka aykırı yollarla girme, bir bilişim sistemini engelleme, bozma, sistemdeki verileri yok etme veya değiştirme, banka veya kredi kartlarının kötüye kullanılması olarak sınıflandırılmıştır. Avrupa Birliği Siber Suç Sözleşmesi'ne (t.y.) göre bilişim suçları veya siber suçlar; yasadışı erişim, yasadışı müdahale, verilere müdahale, sistemlere müdahale ve bu fiilleri gerçekleştirmeye yönelik araç ve yazılım geliştirme; bilişim teknolojileri kullanarak sahtecilik ve dolandırıcılık yapma, çocuk pornografisi, telif haklarının ihlal edilmesi, bilişim suçlarına yardım etmek veya azmettirmek olarak belirtilmektedir. Kurumsal ve bireysel olarak bilgi- lerin çalınması ve kötüye kullanılmasını içeren bu faaliyetler (Sağıroğlu ve Vural, 2008) çeşitli saldırı yöntemleri kullanarak gerçekleştirilmektedir (Canberk ve Sağıroğlu, 2006). Bu faaliyetler arasında şifre ve gizli soru tahmini, omuz sörfü ve çöpe dalma, virüsler, truva atları (trojens), solucanlar, tuş kaydedici yazılımlar (keylogger), ekran kaydedici yazılımlar (screenlogger), casus yazılımlar (spyware), reklam yazılımları (adware), istenmeyen postalar (spam), DoS (Denial of service) saldırıları, robot (bots) ve köle (zombie) yazılımlar, mantık bombaları, SQL enjeksiyon, arka kapilar (back doors), izleme (sniffing) ve gizleme (spoofing) (Gökmen, 2014) sayılabilir.

Computer Crime \& Security (CSI, 2011: 17) kurumu tarafından gerçekleştirilen 2010/2011 y1lı raporuna göre, 2005 ile 2010 yılları arasında gerçekleşen siber saldırı teknikleri ve bu tekniklerin kullanımının yıllara göre dağılımını aşağıdaki gibidir (Tablo 1).

Tablo 1. Computer Crime \& Security Survey 2010/2011, 2005-2010 yılları arası gerçekleşen siber saldırı türlerinin dağılımı

\begin{tabular}{|c|c|c|c|c|c|}
\hline Saldırı Türleri & 2005 & 2007 & 2008 & 2009 & 2010 \\
\hline Kötü Amaçlı Yazılım (Malware) & $\% 74$ & $\% 52$ & $\% 50$ & $\% 64$ & $\% 67$ \\
\hline Kurum içi Yazılım Robotları (Bots) & 2007 'de eklendi & $\% 21$ & $\% 20$ & $\% 23$ & $\% 29$ \\
\hline $\begin{array}{l}\text { Oltalama (phishing) ile bilgilerin çalınması } \\
\text { girişimi }\end{array}$ & 2007 'de eklendi & $\% 26$ & $\% 31$ & $\% 34$ & $\% 39$ \\
\hline Parola dinleme (Password Sniffing) & 2007 'de eklendi & $\% 10$ & $\% 9$ & $\% 17$ & $\% 12$ \\
\hline Finansal Sahtekarlık (Financial fraud) & $\% 9$ & $\% 12$ & $\% 12$ & $\% 20$ & $\% 9$ \\
\hline Dos Atakları (Denial of service) & $\% 32$ & $\% 25$ & $\% 21$ & $\% 29$ & $\% 17$ \\
\hline $\begin{array}{l}\text { Verilerin çalınması ve saldırı tehlikesi ile } \\
\text { şantaj ve zorbalık }\end{array}$ & \multicolumn{3}{|c|}{$2009^{\prime}$ da eklendi } & $\% 3$ & $\% 1$ \\
\hline Web site saldırıları & $\% 6$ & $\% 10$ & $\% 6$ & $\% 14$ & $\% 7$ \\
\hline Kamusal sayfalara yetkisiz erişim & \multicolumn{3}{|c|}{2009 'da eklendi } & $\% 6$ & $\% 7$ \\
\hline Kablosuz ağlara yetkisiz erişim & $\% 16$ & $\% 17$ & $\% 14$ & $\% 8$ & $\% 7$ \\
\hline DNS Sunuculara yetkisiz erişim & $2007^{\prime}$ de eklendi & $\% 6$ & $\% 8$ & $\% 7$ & $\% 2$ \\
\hline İstemci web tarayıcılarına yetkisiz erişim & \multicolumn{3}{|c|}{2009 'da eklendi } & $\% 11$ & $\% 10$ \\
\hline $\begin{array}{l}\text { Kullanıcıların sosyal ağ profillerine yetkisiz } \\
\text { erişim }\end{array}$ & \multicolumn{3}{|c|}{2009 'da eklendi } & $\% 7$ & $\% 5$ \\
\hline Anlık mesajlaşma suiistimalleri & 2007 'de eklendi & $\% 25$ & $\% 21$ & $\% 8$ & $\% 5$ \\
\hline Kurum içi güvenlik ve yetki suiistimalleri & $\% 48 \quad \% 42$ & $\% 59$ & $\% 44$ & $\% 30$ & $\% 25$ \\
\hline $\begin{array}{l}\text { Yetkisiz erişim veya sistem içi imtiyazların } \\
\text { artışı }\end{array}$ & \multicolumn{3}{|c|}{$2009^{\prime}$ da eklendi } & $\% 15$ & $\% 13$ \\
\hline
\end{tabular}




\begin{tabular}{|c|c|c|c|c|c|}
\hline Sistemlere dişarda sızma & $2009^{\prime}$ da ekle & & & $\% 14$ & $\% 11$ \\
\hline $\begin{array}{l}\text { Dizüstü veya mobil cihazların çalınma- } \\
\text { si/yitirilmesi }\end{array}$ & $\% 48$ & $\% 50$ & $\% 42$ & $\% 42$ & $\% 34$ \\
\hline $\begin{array}{l}\text { Mobil cihazların çalınması/yitirilmesi sonu- } \\
\text { cu kişisel bilgilerin çalınması/yetkisiz erişim }\end{array}$ & 2008'de eklendi & & $\% 8$ & $\% 6$ & $\% 5$ \\
\hline $\begin{array}{l}\text { Mobil cihazların çalınması/yitirilmesi sonu- } \\
\text { cu fikri mülkiyete taciz }\end{array}$ & 2008' de eklendi & & $\% 4$ & $\% 6$ & $\% 5$ \\
\hline $\begin{array}{l}\text { Diğer nedenlerden dolayı kişisel bilgilerin } \\
\text { çalınması/yetkisiz erişim }\end{array}$ & 2008' de eklendi & & $\% 8$ & $\% 10$ & $\% 11$ \\
\hline $\begin{array}{l}\text { Diğer nedenlerden dolayı fikri mülkiyete } \\
\text { taciz }\end{array}$ & $2008^{\prime}$ de eklendi & & $\% 5$ & $\% 8$ & $\% 5$ \\
\hline
\end{tabular}

Tablo 1'de görüldüğü gibi gerçekleşme oranı görece yüksek olan: Kötü amaçlı yazılım (Malware), DoS atakları (Denial of service), oltalama (phishing), kurum içi suiistimaller, dizüstü veya mobil cihaz kaynaklı siber suçlar gibi siber saldırılar kullanıcıların önlem alarak kendilerini koruyabilecekleri nitelikte saldırılardır. Symantec tarafından gerçekleştirilen internet güvenliği tehditleri raporunda da belirtildiği gibi güncel güvenlik yazılımlarının kullanılması dışında alınabilecek en önemli önlemlerden biri de bilişim güvenliği ve siber saldırılar konusunda kullanıcıların bilgilendirilmesidir (Symantec, 2014; Şahinaslan, Kandemir ve Şahinaslan, 2009). Çoğunlukla insan faktörüne bağlı olan (Wagner ve Brooke, 2007) bilgi ve bilişim güvenliği risklerini en düşük seviyeye çekebilmek kullanıcıların bilgi ve bilişim güvenliği ilkelerine uygun davranması ile sağlanabilir (Şahinaslan, Kaantürk, Şahinaslan ve Borandağ, 2009).

Ĕ̆itim kurumları bilişim güvenliği farkındalığının oluşturulmasında oldukça önemli görülmektedir. Eğitim fakültelerinde yürütülen ögrretmen yetiştirme programları incelendiğinde bazı Bilgisayar ve Öğretim Teknolojileri Eğitimi programlarında bilişim güvenliği konusu ile ilgili dersler olduğu, diğer öğretmenlik programlarında ise bu tür dersler olmadığı dikkat çekmektedir. Ülkemizde Firsatları Artırma ve Teknolojiyi İyileştirme Hareketi (FATIH) projesi ile beraber eğitim kurumlarında bilişim teknolojilerinin kullanımın yoğunluğu- nun arttığ1 tüm öğretmen ve öğrencilere tabletlerin dağıtıldığı bu dönemde eğitim kurumlarında görev yapacak öğretmenlerin ve öğretmen adaylarının bilişim güvenliği ile ilgili farkındalık düzeyleri önemli bir konu haline gelmektedir.

Bu bağlamda araştırmanın amacı eğitim fakültesi son sınıf öğrencilerinin bilişim güvenliği farkındalıklarını incelemektir. Bu amaç bağlamında aşağıdaki sorulara yanıt aranmıştır.

Eğitim fakültesi son sınıf öğrencilerinin;

1) Bilişim güvenliği ile ilgili:

a) Parola

b) Internetten alış-veriş

c) Bilgisayar kullanıcı hesapları güvenliği

d) Anti-virüs ve zararlı yazımları engelleme

e) Güncelleme

f) Sosyal ăg

g) Eposta ve anlık mesajlaşma yazılımları

h) Kablosuz ağlar

i) Yasal ve etik konular

j) Bilgilerini güncelleme, ilkelerine uyma farkındalık düzeyleri nedir?

2) Öğrencilerin bilişim güvenliği düzeyleriyle ilgili yanıtlarının seçeneklere dağılımı:

a) Cinsiyet

b) Bilgisayar ve internet kullanım yılı

c) Bilişim güvenliği ile alakalı bir eğitim alıp almama durumu, değişkenlerine göre anlamlı farklılık göstermekte midir?

3) Bilişim güvenliği ile ilgili olarak katılımcılar: 
a) Bir alış-veriş sitesinden alış-veriş yaparken sitenin hangi özelliklerine dikkat etmektedirler?

b) Parola belirlerken parolanın hangi özellikleri olmasına dikkat etmektedirler?

c) Bir yazılıma ihtiyaç duyduklarında nasıl temin etmektedirler?

d) Bilişim güvenliği konusunda bilgi aldıkları kaynaklar nelerdir?

\section{YÖNTEM}

$\mathrm{Bu}$ çalışma belirlenmiş bir kitleden veri toplayarak kitlenin özelliklerini ortaya koymaya yöneliktir. Bu nedenle araştırmanın modeli kesitsel tarama modelidir. Kesitsel araştırmalarda değişkenler betimlenmek üzere bir tek seferde ölçülür (Büyüköztürk, Kılıç Çakmak, Akgün, Karadeniz ve Demirel, 2012). Araştırma kapsamında geliştirilen ankette farkındalık düzeyleri incelenmiş ayrıca anket sonunda yer verilen açı uçlu sorularla katılımcıların bilişim güvenliğinde dikkat ettikleri konular belirlenmeye çalışılmıştır.

\subsection{Katılımcilar}

$\mathrm{Bu}$ araştırmanın evrenini Sakarya Üniversitesi Eğitim Fakültesi Bilgisayar ve Öğretim Teknolojileri Eğitimi (BÖTE), İlköğretim Matematik Eğitimi (IME), Türkçe Eğitimi (TRE) ve Zihin Engelliler Eğitimi (ZEÖ) 1. öğretim programlarında okuyan toplam 259 son sinıf lisans öğrencisi oluşturmaktadır. Araştırma evreninde konu alanı uzmanlığı olması beklenen BÖTE bölümü öğrencilerinin yanı sıra bir sayısal, bir sözel ve bir eşit ağırlık programının yer almasına dikkat edilmiştir. Araştırma kapsamında bu evren biriminin tamamına anket ulaştırılmıştır. Anketi gönüllü olarak doldurarak çalışmaya 212 kişi katılmıştır. Analizler 212 kişinin verileri üzerinden yapılmıştır. Örneklemin bölümlere göre dağılımı şu şekildedir: BÖTE 64, İME 39, TRE 74, ZEÖ 35.

\subsection{Veri Toplama Aracı}

$\mathrm{Bu}$ çalışmada veri toplama aracı olarak araştırmacılar tarafından geliştirilen "Bilişim Güvenliği Anketi" kullanılmıştır. Anket geliştirilirken alan yazındaki araştırmalardan ve kullanıcı sayısı en yüksek (donanımhaber, shiftdelete.net, chip.com.tr gibi) forumlarda paylaşılan bilişim güvenliği ile ilgili sorunlardan yola çıarak bir madde havuzu oluşturulmuştur. Özellikle Kritzinger ve Smith'in (2008) temel bilgi güvenliği ilkelerinden yola çıkılarak sorular kategorilere ayrılmıştır. Güvenlik duvarları ve saldırı önleme/sezme sistemleri ilkesi için “Anti-virüs ve zararlı yazılımları engelleme" ve “Güncelleme" başlıkları altında; şifreleme yöntemleri, parola güvenliği ve bireysel parola güvenliği ilkeleri için "Parola" başlığı altında; erişim/yetki kontrolü ilkesi için "Bilgisayar kullanıcı hesapları güvenliği" başlığı altında; yasal yönler ve etik ilkesi için "Yasal ve etik konular" başlığı altında; bilgi güvenliği ve gizliliği kültürü ilkesi için "Bilgilerini güncelleme (bilişim güvenliği ile ilgili)" başlığı altında alan yazın ve forumlarda özellikle son kullanıcıların yaşadığı sorunlar dikkate alınarak anket soruları hazırlanmıştır. Sosyal ağ, eposta ve anlık mesajlaşma yazılımları, kablosuz ağlar başlığı altındaki sorular ise daha çok forumlarda yer alan son kullanıcı sorunları dikkate alınarak hazırlanıp araştırmacılar tarafından eklenmiştir. Anketin kapsam geçerliliği için oluşturulan bu maddelerle ilgili bilişim güvenliği konusunda çalışmış beş alan uzmanından ve ayrıca bir Türkçe uzmanından uzman görüşü alınmıştır. Yeniden düzenlenen bu form 48'i 5'li likert tipi 18'i demografik ve kullanım alışkanlıklarını belirlemeye yönelik toplam 66 sorudan oluşmuştur. Likert tipi hazırlanan soruların yanıt seçenekleri öğrencilerin "Benim için kesinlikle doğru", "Benim için doğru", "Benim için doğru olup olmadığından emin değilim", "Benim için doğru değil” ve "Benim için kesinlikle doğru değil” şeklinde kendilerini 
yakın hissettikleri düzeyde yanıt verebilmeleri için düzenlenmiştir. Anketteki Likert tipi sorular 10 bilişim güvenliği konu başlığı altında toplanmıştır. Bu başlıklar ve soru sayılarının dağılımı şu şekildedir:

- Parola (8 soru)

- İnternetten alış-veriş (3 soru)

- Bilgisayar kullanıcı hesapları güvenliği (5 soru)

- Anti-virüs ve zararlı yazılımları engelleme (6 soru)

- Güncelleme (3 soru)

- $\quad$ Sosyal ağ (5 soru)

- $\quad$ Eposta ve anlık mesajlaşma yazılımları (7 soru)

- Kablosuz ağlar (3 soru)

- Yasal ve etik konular ( 3 soru)

- Bilgilerini güncelleme (bilişim güvenliği ile ilgili) (5 soru)

Geliştirilen bu anketten toplam puan elde edilmemektedir. Her bir soru o soruda ölçülmek istenen özellikle ilgili gerçek durumu ortaya koymaya yöneliktir. Anketin kapsam geçerliği için uzman görüşü temel alınmıştır. Uzmanlar farkındalık düzeyini ölçmeyi hedefleyen tüm soruları ve dolayısıyla anketi kapsam geçerliği açısından yeterli bulmuşlardır. Likert tipi 48 maddenin güvenirliği için Cronbach Alfa iç tutarlık katsayısı hesaplanarak değer .87 bulunmuştur. Maddelerden herhangi biri atıldığında Alfa değeri yükselmemektedir. $\mathrm{Bu}$ bulgular anketin güvenilir kabul edilebileceğini göstermektedir (Büyüköztürk, 2012).
Veriler aşağıda belirtilen üç kategori altında analiz edilmiştir.

1.Ankette yer alan maddelerin toplandiğ 10 konu başlığına yönelik soruların yanıtları ayrı ayrı başlıklar altında verilerek yüzde ve frekans ile betimlenmiştir. Bu bulgular verilirken okumayı ve yorumlamayı kolaylaştırmak amacıyla "Benim için kesinlikle doğru" ile "Benim için doğru” yanıtları birleştirilerek "Benim için doğru" şeklinde; "Benim için doğru değil" ile "Benim için kesinlikle doğru değil" yanıtları da birleştirilerek "Benim için doğru değil" başlığı altında sunulmuştur.

2.Aşağıdaki değişkenlere göre katılımcıların yanıtlarının farklılaşıp farklılaşmadığı iki değişkenli ki-kare ile incelenmiştir.

a) Cinsiyet,

b) Bilgisayar ve Internet kullanım yılı,

c) Bilişim güvenliği ile alakalı bir eğitim alıp almama durumu.

3. Açık uçlu sorulara yönelik verilen yanıtlardan elde edilen temalar ve bunların frekanslarına ait bulgular içerik analizi yapılarak sunulmuştur.

\section{BULGULAR}

Bulgular ankette yer alan maddelerin kategorilendirildiği yukarda belirtilen 10 başlık altında sunulmuştur.

\subsubsection{Parola Sorularına Verilen Yanıtlara Ait Bulgular}

Katılımcıların parola güvenliği ile ilgili verdikleri yanitlar Tablo 2' de sunulmuştur.

\subsection{Verilerin Analizi}

Tablo 2. Parola Sorularına Verilen Yanıtlara Ait Frekans ve Yüzdelikler

\begin{tabular}{llcc}
\hline \multicolumn{1}{c}{ Soru } & & $\mathrm{f}$ & $\%$ \\
\hline \multirow{2}{*}{ S1- Farklı e-posta adreslerim için aynı parolayı (şifreyi) } & Benim için doğru & 129 & 59,5 \\
kullanırım. & Kararsızım & 13 & 6,0 \\
& Benim için doğru değil & 75 & 34,5 \\
\hline
\end{tabular}




\begin{tabular}{llcc}
\hline \multirow{2}{*}{ S2 - Farklı sitelere üye olurken aynı kullanıcı adı ve paro- } & Benim için doğru & 129 & 60,0 \\
layı kullanırım. & Kararsızım & 15 & 7,0 \\
& Benim için doğru değil & 71 & 33,0 \\
\hline \multirow{2}{*}{ S7 - İnternette parolamı yazarken yakın arkadaşlarımın } & Benim için doğru & 109 & 50,7 \\
parolamı görmesi benim için sorun değildir. & Kararsızım & 32 & 14,9 \\
& Benim için doğru değil & 74 & 34,4 \\
\hline \multirow{2}{*}{ S8 - Güvendiğim insanlara kullanıcı adı ve şifremi veri- } & Benim için doğru & 125 & 54,3 \\
rim. & Kararsızım & 25 & 11,7 \\
& Benim için doğru değil & 64 & 30 \\
\hline \multirow{2}{*}{ S13 - Parolamı yönetmek (saklamak) için bir bilgisayar } & Benim için doğru & 37 & 17,5 \\
yazılımı kullanırım. & Kararsızım & 25 & 11,8 \\
& Benim için doğru değil & 150 & 70,7 \\
\hline \multirow{3}{*}{ S28 - Parolamı belirli zaman aralıklarında değiştiririm. } & Benim için doğru & 93 & 43,3 \\
& Kararsızım & 36 & 16,7 \\
\hline \multirow{2}{*}{ S43 - Nasıl güvenli bir parola belirleyeceğim hakkında } & Benim için doğru değil & 86 & 40,0 \\
bilgi sahibiyim. & Benim için doğru & 149 & 71,6 \\
& Kararsızım & 27 & 13,0 \\
\multirow{2}{*}{ S44 - Parola güvenliğinin zayıf, orta, yüksek olmasının } & Benim için doğru değil & 32 & 15,4 \\
\hline parolamın güvenliğini nasıl etkilediğini biliyorum. & Kenim için doğru & 152 & 73,8 \\
& Kararsızım & 27 & 13,1 \\
& Benim için doğru değil & 27 & 13,1 \\
\hline
\end{tabular}

Tablo 2'deki değerler incelendiğinde, öğrencilerin yaklaşık $\% 60^{\prime}$ ının farklı site üyelikleri ve eposta adresleri için aynı kullanıcı adı ve şifreyi kullandıkları ve $\% 54,3$ oranında arkadaşlarına ve güvendikleri insanlara parolalarını gösterdikleri ve söyledikleri görülmektedir. Bu durum öğrencilerin çoğunluğunun parola kullanımı konusunda güvenlik açığı olduğunu bu konuda farkındalıklarının düşük olduğunu göstermektedir. Diğer yandan katılımcıların $\% 71,6$ 'sının nasıl güvenli bir parola belirleyecekleri hakkında bilgi sahibi olduklarını düşündükleri görülmektedir. Ayrıca, katılımcıların $\% 70,7$ oranında parolalarını saklamak ve yönetmek için bilgisayar yazılımı kullanmadıklarını ve parolalarını belirli zaman aralıkları ile değiştirmenin öneminin farkında olanlar

Tablo 3. İnternetten Alış-Veriş Sorularına Verilen Yanıtlara Ait Frekans ve Yüzdeler

\begin{tabular}{llcc}
\hline \multicolumn{1}{c}{ Soru } & & f & $\%$ \\
\hline \multirow{2}{*}{ S4 - Kişisel bilgisayarımın dışındaki bilgisayarlar üzerin- } & Benim için doğru & 62 & 28,6 \\
den internet aracılığı ile alış veriş yaparım. & Kararsızım & 28 & 13,0 \\
& Benim için doğru değil & 126 & 54,8 \\
\hline S5 - İnternette alış-veriş̧ yaparken internetten ödeme & Benim için doğru & 146 & 68,9 \\
güvenliği hakkında nelere dikkat etmem gerektiğini bili- & Kararsızım & 31 & 14,6 \\
rim. & Benim için doğru değil & 35 & 16,5 \\
\hline
\end{tabular}




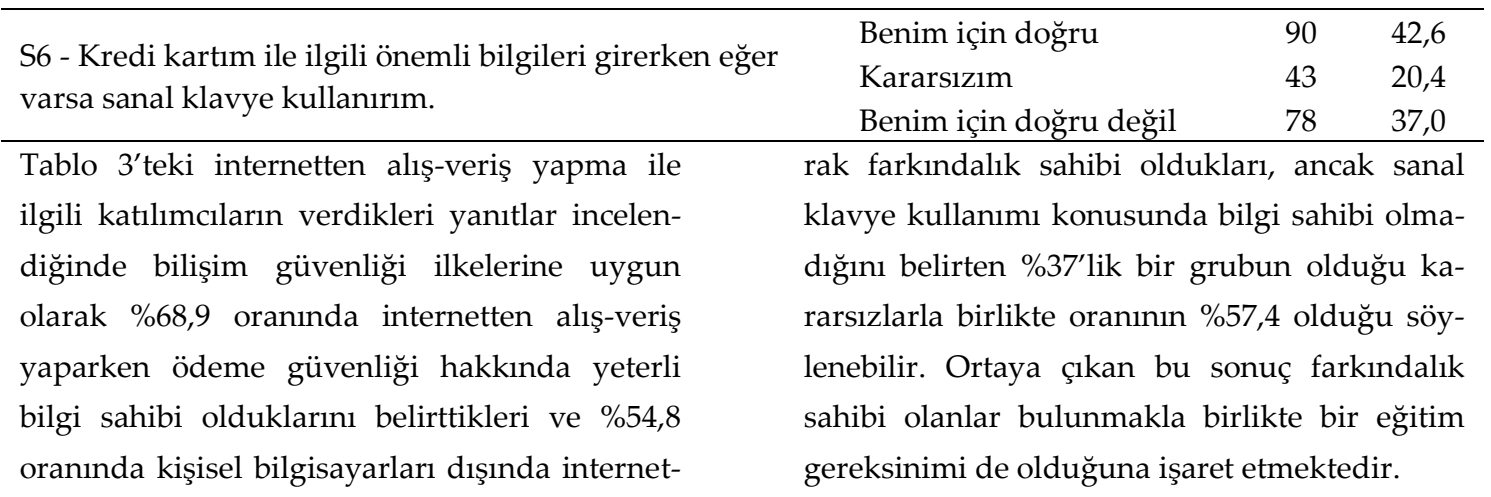

ten alış-veriş yapmadıkları görülmektedir.

Diğer yandan, internetten alış-veriş yaparken sanal klavye kullanımının öneminin, farkında olanlar $(\% 42,6)$ ve olmayanların (\%37) oranları birbirine yakındır. Bu nedenlerden dolayı öğrencilerin internetten alış-veriş konusunda nelere dikkat edecekleri konusunda genel ola-

\subsubsection{Bilgisayar Kullanıcı Hesapları Güvenliği Sorularına Verilen Yanıtlara Ait Bulgular}

Katılımcıların bilgisayar kullanıcı hesapları güvenliği ile ilgili sorulara verdikleri cevaplar

Tablo 4'te sunulmuştur.

Tablo 4. Bilgisayar Kullanıcı Hesapları Güvenliği Sorularına Verilen Yanıtlara Ait Frekans ve Yüzdelikler

\begin{tabular}{|c|c|c|c|}
\hline Soru & & $\mathrm{f}$ & $\%$ \\
\hline \multirow{3}{*}{$\begin{array}{l}\text { S3 - Bana ait olmayan bir bilgisayardan internete girer- } \\
\text { ken, tarayıcının kişisel bilgilerimi kaydedip kaydetmedi- } \\
\text { ğini kontrol ederim. }\end{array}$} & Benim için doğru & 173 & 79,8 \\
\hline & Kararsizim & 20 & 9,2 \\
\hline & Benim için doğru değil & 24 & 11,1 \\
\hline \multirow{3}{*}{ S9 - Bilgisayarımda bir açılış parolası kullanırım. } & Benim için doğru & 131 & 60,6 \\
\hline & Kararsızım & 22 & 10,2 \\
\hline & Benim için doğru değil & 63 & 29,2 \\
\hline \multirow{3}{*}{$\begin{array}{l}\text { S10 - Bilgisayarımı kullanmak isteyen kişiler için açtığım, } \\
\text { ayrı, sınırlı bir oturum vardır. }\end{array}$} & Benim için doğru & 58 & 27,0 \\
\hline & Kararsızım & 16 & 7,4 \\
\hline & Benim için doğru değil & 141 & 65,6 \\
\hline \multirow{3}{*}{$\begin{array}{l}\text { S11 - Bilgisayarımda kendi oturumumdaki önemli belge- } \\
\text { ler şifreli haldedir. }\end{array}$} & Benim için doğru & 72 & 34,0 \\
\hline & Kararsızım & 25 & 11,8 \\
\hline & Benim için doğru değil & 115 & 54,2 \\
\hline \multirow{3}{*}{$\begin{array}{l}\text { S12 - Bilgisayarımı kullanmak isteyen olursa sadece ko- } \\
\text { nuk oturumunu kullanmasına izin veririm. }\end{array}$} & Benim için doğru & 154 & 72,0 \\
\hline & Kararsızım & 19 & 8,9 \\
\hline & Benim için doğru değil & 41 & 19,1 \\
\hline
\end{tabular}

Katılımcıların bilgisayar kullanıcı güvenliği ile ilgili verdikleri yantllar incelendiğinde (bkz. Tablo 4) \%65,6 oranında öğrencilerin kendi bilgisayarlarını kullanmak isteyenler için misafir veya konuk oturumu kullanmadiğ 1 ve \%54,2 oranında öğrencilerin bilgisayarında önemli belgelerin şifreli olmadığı görülmektedir. Diğer yandan yanıtların \%79,8'i öğrencilerin başka bir bilgisayardan internete girerken tarayıcının kişisel bilgilerini kaydedip kaydetmediğini kontrol ettiği ve \%60,6 oranında bilgisayarlarında açılış parolası kullandıklarını ifade etmektedirler. Öğrenciler bir taraftan konuk oturumlarının olmadığını belirtirken $(\% 65,6)$ diğer taraftan bilgisayarlarını başkasına verirken konuk oturumunda verdiklerini belirtmek- 
tedirler (\%72). Bu durum öğrencilerin bu konuda çelişen yanıtların olduğunu göstermektedir.

\subsubsection{Anti-Virüs ve Zararlı Yazılımları Engel-} leme Sorularına Verilen Yanitlara Ait Bulgular

Tablo 5. Anti-Virüs ve Zararlı Yazılımları Engelleme Sorularına Verilen Yanıtlara Ait Frekans ve Yüzdelikler

\begin{tabular}{|c|c|c|c|}
\hline \multicolumn{2}{|l|}{ Soru } & $\mathrm{f}$ & $\%$ \\
\hline \multirow{3}{*}{$\begin{array}{l}\text { S21 - Internetten bilgisayarıma indirdiğim dosyaları aç- } \\
\text { madan önce virüs taramasından geçiririm. }\end{array}$} & Benim için doğru & 113 & 52,8 \\
\hline & Kararsızım & 43 & 20,1 \\
\hline & Benim için doğru değil & 58 & 27,1 \\
\hline \multirow{3}{*}{$\begin{array}{l}\text { S22 - USB Bellek, harici disk veya cd-dvd medyası bilgi- } \\
\text { sayarıma bağlandığında öncelikle anti-virüs taramasın- } \\
\text { dan geçiririm. }\end{array}$} & Benim için doğru & 125 & 68,2 \\
\hline & Kararsızım & 36 & 16,7 \\
\hline & Benim için doğru değil & 54 & 25,1 \\
\hline \multirow{3}{*}{$\begin{array}{l}\text { S29 - Bilgisayarımı belli zaman aralıklarında güvenlik } \\
\text { taramasından geçiririm. }\end{array}$} & Benim için doğru & 130 & 61,0 \\
\hline & Kararsızım & 39 & 18,3 \\
\hline & Benim için doğru değil & 34 & 20,7 \\
\hline \multirow{3}{*}{$\begin{array}{l}\text { S35 - İnternet kaynaklı tehditler ile ilgili yeterli bilgiye } \\
\text { sahibim. }\end{array}$} & Benim için doğru & 105 & 49,1 \\
\hline & Kararsızım & 65 & 30,4 \\
\hline & Benim için doğru değil & 44 & 10,5 \\
\hline \multirow{3}{*}{$\begin{array}{l}\text { S42 - İnternet tarayıcım vasıtasıyla internette gezindiğim } \\
\text { web sitelerinin güvenirliği ile ilgili bilgi edinmeye çalışı- } \\
\text { rım. }\end{array}$} & Benim için doğru & 92 & 45,5 \\
\hline & Kararsızım & 58 & 28,0 \\
\hline & Benim için doğru değil & 57 & 27,5 \\
\hline \multirow{3}{*}{$\begin{array}{l}\text { S48 - Bilgisayarın güvenliğini sağlayacak yazılımları } \\
\text { bulma ve kullanmada yeterli bilgiye sahibim. }\end{array}$} & Benim için doğru & 101 & 49,5 \\
\hline & Kararsızım & 53 & 26,0 \\
\hline & Benim için doğru değil & 50 & 24,5 \\
\hline \multirow{11}{*}{$\begin{array}{l}\text { Tablo 5’te öğrencilerin verdikleri yanıtlar ince- } \\
\text { lendiğinde bilişim güvenliği ilkelerine uygun } \\
\text { olarak, öğrencilerin yarıdan fazlasının virüs } \\
\text { taraması yapma konusunda farkındalık sahibi } \\
\text { oldukları görülmektedir. Diğer yandan internet } \\
\text { kaynaklı tehditler (\%49,1) ve bilişim güvenliği } \\
\text { sağlayacak yazılımları bulma ve kullanma } \\
\text { konusunda yeterli olduğunu düşünenler } \\
\text { (\%49,5) ile internet kaynaklı tehditler konusun- } \\
\text { da yetersiz ve kendinden emin olmayanların } \\
\text { toplam oranı (\%40,9) ve bilişim güvenliği sağ- } \\
\text { layacak yazılımları bulma ve kullanma konu- }\end{array}$} & \multirow{11}{*}{\multicolumn{3}{|c|}{$\begin{array}{l}\text { sunda yetersiz ve kendinden emin olmayanla- } \\
\text { rın toplam oranı }(\% 50,5) \text { birbirine yakındır. Bu } \\
\text { nedenle dikkate alınır düzeyde farkındalığın } \\
\text { düşük olduğu ve bu konularda bilgi eksikliği } \\
\text { olabileceği söylenebilir. } \\
\text { 3.1.5 Güncelleme Sorularına Verilen Yanıtlara } \\
\text { Ait Bulgular } \\
\text { Katılımcıların işletim sistemi, güvenlik yazılımı } \\
\text { ve ofis yazılımlarının güncellemesi ile ilgili } \\
\text { sorulara verdikleri yanıtlar Tablo 6'da sunul- } \\
\text { muştur. }\end{array}$}} \\
\hline & & & \\
\hline & & & \\
\hline & & & \\
\hline & & & \\
\hline & & & \\
\hline & & & \\
\hline & & & \\
\hline & & & \\
\hline & & & \\
\hline & & & \\
\hline \multicolumn{4}{|c|}{ Tablo 6. Güncelleme Sorularına Verilen Yanıtlara Ait Frekans ve Yüzdelikler } \\
\hline Soru & & $\mathrm{f}$ & $\%$ \\
\hline \multirow{3}{*}{$\begin{array}{l}\text { S14 - Kullandığım anti-virüs yazılımının güncelliğini } \\
\text { denetlerim. }\end{array}$} & Benim için doğru & 136 & 63,8 \\
\hline & Kararsızım & 23 & 10,8 \\
\hline & Benim için doğru değil & 54 & 25,4 \\
\hline
\end{tabular}

Katılımcıların anti-virüs ve zararlı yazılımları engelleme konularıla ilgili sorulara verdikleri yanitlar Tablo 5'te sunulmuştur. 


\begin{tabular}{llcc}
\hline \multirow{2}{*}{ S15 - İşletim sistemi güncellemelerini kontrol eder ve } & Benim için doğru & 112 & 52,4 \\
zamanında yüklerim. & Kararsızım & 36 & 16,8 \\
& Benim için doğru değil & 54 & 30,8 \\
\hline \multirow{2}{*}{ S16 - Kullandığım ofis yazılımlarının güncellemelerini } & Benim için doğru & 112 & 53,5 \\
denetlerim. & Kararsızım & 39 & 18,7 \\
& Benim için doğru değil & 58 & 27,8 \\
\hline
\end{tabular}

Güncelleme konusu ile ilgili bulgulara bakıld1ğında (bkz. Tablo 6) genel olarak öğrencilerin yarıdan fazlasının güncelleme ile ilgili konularda farkındalık sahibi oldukları ve güncelleme ile ilgili hususlara dikkat ettikleri görülmektedir. Bununla birlikte kararsiz olanların ve olumsuz yanit verenlerin \%25-\%31 dolaylarındaki oranı bu konuda önemli düzeyde farkın- dalık eksikliği yaşayan katılımcılar olduğunu göstermektedir.

\subsubsection{Sosyal Ağ Sorularına Verilen Yanitlara Ait Bulgular}

Katılımcıların sosyal ağ konularıla ilgili sorularına verdikleri yanıtlar Tablo 7'de sunulmuştur.

Tablo 7. Sosyal Ağ Sorularına Verilen Yanıtlara Ait Frekans ve Yüzdelikler

\begin{tabular}{llcc}
\hline \multicolumn{1}{c}{ Soru } & & $\mathrm{f}$ & $\%$ \\
\hline \multirow{2}{*}{ S18 - Sosyal ağ sitelerinde tanımadığım insanları arkadaş } & Benim için doğru & 36 & 17,0 \\
listeme eklerim. & Kararsızım & 17 & 8,0 \\
& Benim için doğru değil & 159 & 75,0 \\
\hline \multirow{3}{*}{ S19 - Sosyal ağlarda kişisel bilgilerimi paylaşırım. } & Benim için doğru & 39 & 18,8 \\
& Kararsızım & 35 & 16,8 \\
& Benim için doğru değil & 134 & 64,4 \\
\hline \multirow{2}{*}{ S26 - Sosyal ağlarda tanıştığım insanlarla yüz yüze bulu- } & Benim için doğru & 46 & 21,5 \\
şurum. & Kararsızım & 26 & 12,1 \\
& Benim için doğru değil & 142 & 66,4 \\
\hline \multirow{2}{*}{ S27- Kişisel fotoğraf ve videolarımı herkesin erişebileceği } & Benim için doğru & 51 & 23,8 \\
ortamlarda paylaşırım. & Kararsızım & 28 & 13,1 \\
& Benim için doğru değil & 135 & 63,1 \\
\hline S40 - Sosyal medya platformlarında bulunan kullanıcı & Benim için doğru & 139 & 67,8 \\
hesaplarımın gizlilik ayarlarını yönetebilecek bilgiye & Kararsızım & 34 & 16,6 \\
sahibim. & Benim için doğru değil & 32 & 15,6 \\
\hline
\end{tabular}

Tablo 7'deki öğrencilerin verdikleri yanıtlar incelendiğinde öğrencilerin \%60'ından fazlasının sosyal ağlardaki gizlilik ve kişisel bilgilerin korunması ile alakalı konuları önemsedikleri ve bu konularla ilgili düzenlemeleri kişisel sosyal ağ hesaplarında yapabildikleri görülmektedir. $\mathrm{Bu}$ sorulara verilen yanıtlar öğrencilerin sosyal ağlarda gizlilik ve güvenlik konusunda diğer konulara göre daha duyarlı olduklarını göstermektedir. Bununla birlikte diğer başlıklara oranla daha az olsa da \%16 - \%24 dolaylarında farkındalık eksikliği bulunan dikkate alınır düzeyde öğrenci bulunmaktadır.

\subsubsection{Eposta ve Anlık Mesajlaşma Yazılımları Güvenliği Sorularına Verilen Yanıtlara Ait Bulgular}

Katılımcıların e-posta kullanımı ve anlık mesajlaşma yazılımı kullanımı güvenliği ile ilgili sorulara verdikleri yantlar Tablo 8'de sunulmuştur. 
Tablo 8. Eposta ve Anlık Mesajlaşma Yazılımları Güvenliği Sorularına Verilen Yanıtlara Ait Frekans ve Yüzdelikler

\begin{tabular}{|c|c|c|c|}
\hline Soru & & $\mathrm{f}$ & $\%$ \\
\hline \multirow{3}{*}{$\begin{array}{l}\text { S17 - Anında ileti yazılımı kullanarak benimle dosya } \\
\text { paylaşıldığında gelen dosya ile ilgili bilgim yoksa gönde- } \\
\text { ren kişiye sormadan dosyayı açmam. }\end{array}$} & Benim için doğru & 104 & 49,3 \\
\hline & Kararsızım & 54 & 25,6 \\
\hline & Benim için doğru değil & 33 & 25,1 \\
\hline \multirow{3}{*}{$\begin{array}{l}\text { S20 - Gönderenini tanımadığım bir epostaya eklenmiş } \\
\text { dosyayı anti-virüs taramasından geçirmeden açarım. }\end{array}$} & Benim için doğru & 59 & 24,7 \\
\hline & Kararsızım & 38 & 17,7 \\
\hline & Benim için doğru değil & 118 & 54,6 \\
\hline \multirow{3}{*}{$\begin{array}{l}\text { S30 - Göndereni tanımasam da tepkimi çeken postaları } \\
\text { yanıtlarım. }\end{array}$} & Benim için doğru & 53 & 35,0 \\
\hline & Kararsızım & 35 & 16,5 \\
\hline & Benim için doğru değil & 174 & 58,5 \\
\hline \multirow{3}{*}{$\begin{array}{l}\text { S31 - Anında ileti yazılımları kullanırken yazışmaları } \\
\text { arşivlerim. }\end{array}$} & Benim için doğru & 52 & 24,9 \\
\hline & Kararsızım & 42 & 19,9 \\
\hline & Benim için doğru değil & 107 & 50,2 \\
\hline \multirow{3}{*}{$\begin{array}{l}\text { S34 - Eposta adresime gelen sahte içerikli postaları } \\
\text { "Spam" olarak işaretlerim. }\end{array}$} & Benim için doğru & 114 & 49,3 \\
\hline & Kararsızım & 44 & 21,1 \\
\hline & Benim için doğru değil & 41 & 19,6 \\
\hline \multirow{3}{*}{$\begin{array}{l}\text { S37 - Eposta adresim kötü niyetli kişilerin eline geçerse, } \\
\text { nasıl geri alabileceğim konusunda bilgi sahibiyim. }\end{array}$} & Benim için doğru & 83 & 39,5 \\
\hline & Kararsızım & 58 & 27,6 \\
\hline & Benim için doğru değil & 69 & 32,9 \\
\hline \multirow{3}{*}{$\begin{array}{l}\text { S38 - Göndereni tanımadığım halde ilgimi çeken eposta- } \\
\text { ları yanıtlarım. }\end{array}$} & Benim için doğru & 53 & 25,4 \\
\hline & Kararsızım & 27 & 12,9 \\
\hline & Benim için doğru değil & 129 & 61,7 \\
\hline
\end{tabular}

Tablo 8'de yer alan değerler incelendiğinde öğrencilerin çoğunun bilişim güvenliği ilkelerine uygun olarak gönderenini tanımadıkları eposta ve dosyaları anti-virüs taramasından geçirmeden açmadıklarını $(\% 49,3)$, göndereni tanımadıkları mesajları yanıtlamadıklarını belirttikleri $(\% 58,5)$ görülmektedir. Diğer yandan öğrencilerin eposta adresleri kötü niyetli kişilerin eline geçerse, nasıl geri alabilecekleri konusunda önemli oranda kararsız $(\% 27,6)$ ve yeterli bilgi sahibi olmadıkları $(\% 32,9)$ görülmektedir. Bu başlık altında alınan yanıtlar birlikte dikkate alındığında güvenlik konularına dikkat edenlerin yanitları ile kararsız olan ve olumsuz yanitların toplam oranı birbirine yakın çıkmaktadır. Bu bulgu önemli sayıda öğrencinin e-posta ve anlık ileti güvenliğine dikkat ettiği bununla birlikte tehditlerin farkında olmayan önemli düzeyde katılımcı olduğu şeklinde yorumlanabilir.

\subsubsection{Kablosuz Ağ Güvenliği Sorularına Veri- len Yanıtlara Ait Bulgular}

Katılımcıların kablosuz ağ güvenliği ile ilgili sorulara verdikleri yanitlar Tablo 9'da sunulmuştur.

Tablo 9. Kablosuz Ağ Güvenliği Sorularına Verilen Yanıtlara Ait Frekans ve Yüzdelikler

\begin{tabular}{llcc}
\hline \multicolumn{1}{c}{ Soru } & & $\mathrm{f}$ & $\%$ \\
\hline \multirow{2}{*}{ S23 - Cep telefonum ya da bilgisayarım ile kaynağ1- } & Benim için doğru & 70 & 39,4 \\
nı/sahibini bilmediğim kablosuz ağlara bağlanırım. & Kararsızım & 31 & 14,5 \\
& Benim için doğru değil & 113 & 48,1 \\
\hline \multirow{2}{*}{ S32- Şifrelenmemiş ve kimin sağladığını bilmediğim } & Benim için doğru & 70 & 32,7 \\
kablosuz ağlara bağlanırım. & Kararsızım & 30 & 14,0 \\
& Benim için doğru değil & 114 & 53,3 \\
\hline
\end{tabular}




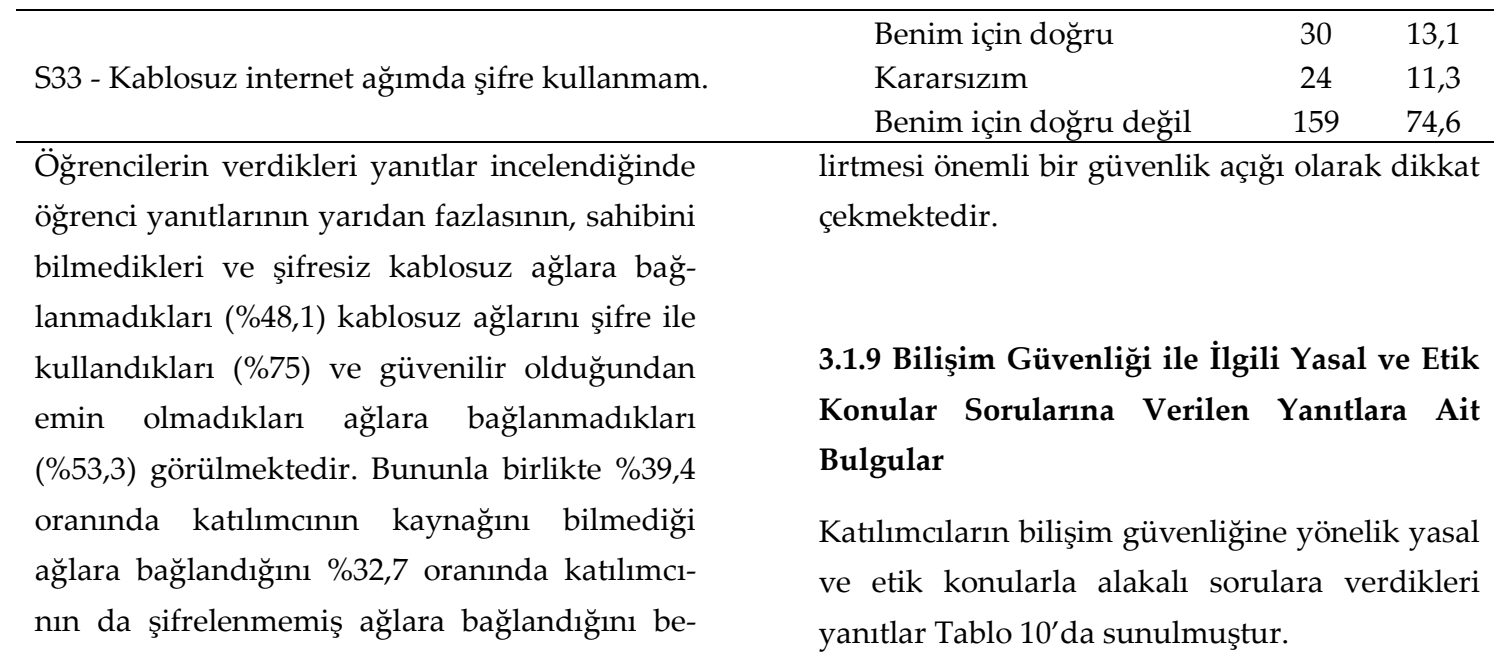

Tablo 10. Bilişim Güvenliği ile İlgili Yasal ve Etik Konular Sorularına Verilen Yanıtlara Ait Frekans ve Yüzdelikler

\begin{tabular}{llcc}
\hline \multicolumn{1}{c}{ Soru } & & $\mathrm{f}$ & $\%$ \\
\hline \multirow{2}{*}{ S24 - Bilgisayarımdaki yazılımları lisans bedellerini öde- } & Benim için doğru & 49 & 23,5 \\
yerek satın aldıktan sonra kullanırım. & Kararsızım & 54 & 25,8 \\
& Benim için doğru değil & 106 & 50,7 \\
\hline \multirow{2}{*}{ S25- Bilgisayarımda yasa dışı yolla edinilmiş (kırılmış) } & Benim için doğru & 78 & 37,0 \\
yazılımlar bulunmaktadır. & Kararsızım & 34 & 16,1 \\
& Benim için doğru değil & 99 & 46,9 \\
\hline \multirow{2}{*}{ S39 - Yazılım kullanmada telif hakları konusunda yeterli } & Benim için doğru & 82 & 40,6 \\
bilgi sahibiyim. & Kararsızım & 61 & 30,2 \\
& Benim için doğru değil & 59 & 29,2 \\
\hline
\end{tabular}

Bilişim teknolojilerinin kanuni ve etik kullanımı konusunda önemli düzeyde bilgilendirme ihtiyacı olduğu ve bu konuda farkındalığın az olduğu görülmektedir.

\subsubsection{Bilişim Güvenliği ile İlgili Bilgilerini Güncelleme Sorularına Verilen Yanıtlara Ait Bulgular}

Öğrencilerin bilişim güvenliğiyle ilgili bilgilerini yenilemeye yönelik sorulara verdikleri yantllar Tablo 11'de sunulmuştur. (\%37) lisansh yazilim kullanım oranından $(\% 23,5)$ yüksek görünmektedir.

Tablo 11. Bilişim Güvenliği ile İlgili Bilgilerini Güncelleme Sorularına Verilen Yanıtlara Ait Frekans ve Yüzdelikler

\begin{tabular}{llcc}
\hline \multicolumn{1}{c}{ Soru } & & $\mathrm{f}$ & $\%$ \\
\hline \multirow{2}{*}{ S36 - Kullandığım internet tarayıcısının güvenlik ayarları } & Benim için doğru & 130 & 61,9 \\
hakkında yeterli bilgi sahibiyim. & Kararsızım & 50 & 23,8 \\
& Benim için doğru değil & 30 & 14,3 \\
\hline S41 - İnternet tarayıcım vasıtasıyla internette gezindiğim & Benim için doğru & 133 & 64,0 \\
web sitelerinin güvenirliği ile ilgili bilgi edinmeye çalışı- & Kararsızım & 47 & 22,5 \\
rım. & Benim için doğru değil & 28 & 13,5 \\
\hline
\end{tabular}




\begin{tabular}{|c|c|c|c|c|c|c|}
\hline \multirow{3}{*}{\multicolumn{2}{|c|}{$\begin{array}{l}\text { S45 - Bilişim güvenliği konusunda bilgi alabileceğim } \\
\text { adresleri bilirim. }\end{array}$}} & \multicolumn{3}{|c|}{ Benim için doğru } & 99 & 47,9 \\
\hline & & \multicolumn{3}{|c|}{ Kararsızım } & 64 & 30,9 \\
\hline & & \multicolumn{3}{|c|}{ Benim için doğru değil } & 44 & 21,2 \\
\hline \multirow{3}{*}{\multicolumn{2}{|c|}{$\begin{array}{l}\text { S46 - Bir bilişim suçuna maruz kalırsam kime başvuraca- } \\
\text { ğımı biliyorum. }\end{array}$}} & \multicolumn{3}{|c|}{ Benim için doğru } & 94 & 45,4 \\
\hline & & \multicolumn{3}{|c|}{ Kararsızım } & 57 & 27,5 \\
\hline & & \multicolumn{3}{|c|}{ Benim için doğru değil } & 54 & 27,1 \\
\hline \multirow{3}{*}{\multicolumn{2}{|c|}{$\begin{array}{l}\text { S47 - Bir bilişim güvenliği sitesini düzenli olarak takip } \\
\text { ederim. }\end{array}$}} & \multirow{3}{*}{\multicolumn{3}{|c|}{$\begin{array}{l}\text { Benim için doğru } \\
\text { Kararsızım } \\
\text { Benim için doğru değil } \\
\end{array}$}} & 51 & 24,6 \\
\hline & & & & & 61 & 29,5 \\
\hline & & & & & 95 & 45,9 \\
\hline \multirow{5}{*}{\multicolumn{2}{|c|}{$\begin{array}{l}\text { Öğrencilerin Tablo } 11^{\prime} \text { de verdikleri yanıtlar } \\
\text { incelendiğinde öğrenci yanıtlarının \%61,9'unun } \\
\text { kullandıkları web tarayıcısının güvenlik ayar- } \\
\text { larını ve web tarayıcıları aracilığı ile girdikleri } \\
\text { sitelerin güvenilirliğini test etmede bilgi sahibi } \\
\text { olduklarını belirttikleri görülmektedir. Diğer } \\
\text { yandan öğrencilerin bilişim suçuna maruz } \\
\text { kaldıklarında veya bilişim güvenliği ile ilgili bir } \\
\text { konuda nereye danışacaklarını bilme oranları } \\
\text { (\%45,4) ile bilmeme (\%27,1) ile emin olmama } \\
\text { (\%27,5) oranlarının toplamı (\%55,6) arasında } \\
\text { bilgi eksikliği lehine bir oran dikkat çekmekte- } \\
\text { dir. Benzer durum düzenli bir şekilde bir bili- } \\
\text { şim güvenliği web sitesini takip etme açısından }\end{array}$}} & \multicolumn{5}{|c|}{$\begin{array}{l}\text { da görülmektedir. Bu nedenle ögrrencilerin bu } \\
\text { konuda yeteri kadar farkındalık sahibi olma- }\end{array}$} \\
\hline & & \multirow{2}{*}{\multicolumn{5}{|c|}{$\begin{array}{l}\text { dıkları ve öğrencilerin bilgilerini güncelleme ve } \\
\text { bir siber suçla karşı karşıya kaldıklarında kime } \\
\text { başvuracaklarını bilme açısından eksiklikleri- }\end{array}$}} \\
\hline & & & & & & \\
\hline & & \multicolumn{5}{|c|}{$\begin{array}{l}\text { Dağılımının Farklılık Gösterdiği Sorulara } \\
\text { İlişkin Bulgular }\end{array}$} \\
\hline & & \multicolumn{5}{|c|}{$\begin{array}{l}\text { Katılımcıların verdikleri yanıtlar cinsiyet de } \\
\text { ğişkenine göre çaprazlandığında dağılımın } \\
\text { anlamlı farklılık gösterdiği sorular Tablo } 12 \text { 'de } \\
\text { verilmiştir. }\end{array}$} \\
\hline \multicolumn{7}{|c|}{ Tablo 12. Cinsiyete Göre Kay-Kare Testi Sonuçları } \\
\hline \multirow{2}{*}{\multicolumn{2}{|c|}{$\mathrm{u}$}} & & rkek & & $\mathrm{sd}$ & \\
\hline & & $\%$ & $\%$ & & $\mathrm{sd}$ & $\mathrm{p}$ \\
\hline \multirow{3}{*}{$\begin{array}{l}\text { S23 - Cep telefonu ya da bilgisayar } \\
\text { ile kaynağını/sahibini bilmediğim } \\
\text { kablosuz ağlara bağlanırım. }\end{array}$} & Benim için doğru & 28,2 & $\underline{48,8}$ & & & \\
\hline & Kararsizım & 12,9 & & 13,58 & 4 & 008 \\
\hline & Benim için doğru değil & $\underline{58,9}$ & 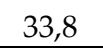 & & & \\
\hline \multirow{3}{*}{$\begin{array}{l}\text { S26 - İnternette, sosyal ağlarda, } \\
\text { anında ileti yazılımlarıyla tanışt1- } \\
\text { ğım bir insan ile yüz yüze görüşü- } \\
\text { rüm. }\end{array}$} & \multirow{3}{*}{$\begin{array}{l}\text { Benim için doğru } \\
\text { Kararsızım } \\
\text { Benim için doğru değil }\end{array}$} & 13,0 & 33,7 & & & \\
\hline & & 8,8 & 16,2 & & & \\
\hline & & $\underline{78,2}$ & $\underline{50,1}$ & 2,31 & 4 & 000 \\
\hline \multirow{3}{*}{$\begin{array}{l}\text { S27 - Kişisel fotoğraf ve videola- } \\
\text { rımı herkesin erişebileceği ortam- } \\
\text { larda paylaşırım. }\end{array}$} & & 16 & 35 & & & \\
\hline & Kararsizım & 9,6 & 18,8 & 24,92 & 4 & \\
\hline & Benim için doğru değil & $\underline{74,4}$ & $\underline{46,0}$ & & & \\
\hline & Benim için doğru & 19,5 & 32,9 & & & \\
\hline ter & Kararsızım & 12,1 & 23,5 & 13,72 & 4 & \\
\hline & Benim için doğru değ & $\underline{68,4}$ & $\underline{43,6}$ & & & 0 \\
\hline S32- Şifrelenmemiş ve kimin sağ- & Benim için doğru & 28,8 & 38,8 & & & \\
\hline ladığını bilmediğim kablosuz ağla- & Kararsızım & 8,8 & 22,3 & 14,71 & 4 & \\
\hline ra bağlanırım. & Benim için doğru c & $\underline{62,4}$ & 38,9 & & & \\
\hline S37 - E-posta adresim kötü niyetli & Benim için doğru & 29,2 & $\underline{54,7}$ & & & \\
\hline & Kararsızım & 34,6 & & 15,62 & 4 & \\
\hline $\begin{array}{l}\text { alabileceğim konusunda bilgi sahi- } \\
\text { biyim. }\end{array}$ & Benim için doğru c & $\underline{36,2}$ & 27,9 & & 4 & ,003 \\
\hline
\end{tabular}




\begin{tabular}{llcccccc}
\hline S46 - Bir bilişim suçuna maruz & Benim için doğru & $\underline{\mathbf{3 7}}$ & $\mathbf{5 7 , 7}$ & & & \\
kalırsam kime başvuracağımı bili- & Kararsızım & 30,3 & $\mathbf{2 3 , 5}$ & 11,65 & 4 & \multirow{2}{*}{020} \\
yorum. & Benim için doğru değil & 32,7 & 18,8 & & & \\
\hline S48 - Bilgisayarımın güvenliğini & Benim için doğru & $\underline{\mathbf{4 0 , 1}}$ & $\mathbf{6 3 , 2}$ & & & \\
sağlayacak yazılımları bulma ve & Kararsızım & $\mathbf{2 8 , 3}$ & $\mathbf{2 2 , 6}$ & $\mathbf{1} 12,90$ & 4 & \multirow{2}{*}{009} \\
kullanmada yeterli bilgiye sahibim. & Benim için doğru değil & 31,6 & 14,2 & & & \\
\hline
\end{tabular}

Tablo 12' deki bulgulara bakıldığında cep telefonu ile kaynağı bilinmeyen kablosuz ağlara erkeklerin $(\% 48,8)$ kızlara göre $(\% 28,2)$ daha yüksek oranda bağlandıkları görülmektedir. Erkek öğrencilerin \%50,1'i sosyal ağlarda tanıştıkları insanlarla yüz-yüze görüşmekten kaçınırken, kız öğrencilerde ise \%78,2 oranında bu durumdan kaçmaktadırlar. Erkek katılımcıların $\% 35,2$ 'si kişisel fotoğraf ve videolarını herkesin erişebileceği sanal ortamlarda paylaşırken bu duruma kizların \%74,4'ü olumsuz yanit vermektedir. Erkeklerin \%32,9'u göndereni tanımasa da tepkisini çeken mesajları yantlarken k1zlarda bu oran $\% 19,5^{\prime}$ dir. Kizlar $(\% 62,4)$ erkeklere göre $(\% 38,8)$ şifrelenmemiş kablosuz ağlara daha az bağlanmaktadırlar. Erkek katılımcılar e-posta adresleri ele geçirilirse $(\% 54,7)$ yada bir bilişim suçuna maruz kalırlarsa $(\% 57,7)$ kızlara göre $(\% 29,2$ ve $\% 37)$ ne yapacakları konusunda daha bilgili olduklarını belirtmektedirler. Benzer biçimde bilgisayar ve yazılım güvenliği konusunda da erkekler $(\% 63,2)$ k1zlara göre $(\% 40,1)$ daha bilgili olduk- larını belirtmektedirler. Tüm bu bulgular dikkate alındığında yukarıda belirtilen bazı bilişim güvenliği konularında kızların erkeklere göre farkındalık sahibi oldukları söylenebilir.

\subsubsection{Bilgisayar ve İnternet Kullanım Yılına Göre Yanıtların Dağılımının Anlamlı Farklı- lık Gösterdiği Kay-Kare Testi Sonuçları}

Ankette katılımcllara bilgisayar ve interneti kaç yıl kullandığı sorulmuştur. Daha sonra öğrencilerin ortalama bilgisayar ve internet kullanım yılları hesaplanmıştır. Öğrencilerin ortalama bilgisayar kullanım süreleri 8,8 yıl, ortalama internet kullanım süreleri ise 7,8 yll olarak hesaplanmış olup öğrencilerin ortalama bilgisayar kullanımı ve internet kullanımı, sürelerinin ortalamanın altında veya üstünde olma durumlarına göre, anket maddeleri ile her madde bazında anlamlı bir farklılık oluşturup oluşturmayacağı incelenmiştir. Anlamlı farklılık gösteren maddeler aşağıdaki tabloda verilmiştir.

Tablo 13. Ortalama Bilgisayar Kullanımı Göre Kay-Kare Testi Sonuçları

\begin{tabular}{|c|c|c|c|c|c|c|}
\hline Soru & & $\begin{array}{l}\text { Ortalamanın } \\
\text { Üstü }(\%)\end{array}$ & $\begin{array}{l}\text { Ortalamanin } \\
\text { Altı }(\%)\end{array}$ & $\chi^{2}$ & $\mathrm{sd}$ & $\mathrm{p}$ \\
\hline \multirow{3}{*}{$\begin{array}{l}\text { S3 - Bana ait olmayan bir bilgi- } \\
\text { sayardan internete girerken, } \\
\text { tarayıcının kişisel bilgilerimi } \\
\text { kaydedip kaydetmediğini kont- } \\
\text { rol ederim. }\end{array}$} & $\begin{array}{l}\text { Benim için doğ- } \\
\text { ru }\end{array}$ & $\underline{71,0}$ & $\underline{61,1}$ & \multirow{3}{*}{27,92} & \multirow{3}{*}{4} & \multirow{3}{*}{,000 } \\
\hline & Kararsızım & 4,0 & 8,4 & & & \\
\hline & $\begin{array}{l}\text { Benim için doğ- } \\
\text { ru değil }\end{array}$ & 35,0 & 30,5 & & & \\
\hline \multirow{3}{*}{$\begin{array}{l}\text { S21 - İnternetten bilgisayarıma } \\
\text { indirdiğim dosyaları açmadan } \\
\text { önce virüs taramasından geçiri- } \\
\text { rim. }\end{array}$} & $\begin{array}{l}\text { Benim için doğ- } \\
\text { ru }\end{array}$ & $\underline{48,9}$ & $\underline{58,0}$ & \multirow{3}{*}{13,79} & \multirow{3}{*}{5} & \multirow{3}{*}{,017 } \\
\hline & Kararsızım & 23,5 & 14,7 & & & \\
\hline & $\begin{array}{l}\text { Benim için doğ- } \\
\text { ru değil }\end{array}$ & 27,6 & 27,3 & & & \\
\hline
\end{tabular}


Bilgisayar kullanım yılı ortalamanın üzerinde olan öğrencilerin, ortalamanın altında olan öğrencilere kıyasla internet tarayıcılarının kişisel bilgi güvenliği konusunda daha farkındalık sahibi oldukları görülmektedir. İnternetten indirilen dosyaların açılmadan önce incelenmesi konusunda ise ortalamanın altındaki grup daha çok farkındalık sahibidir. Bu bulgular bilgisayar kullanma süresinin bazı konularda farkındalığa yol açarken bazı konularda farkındalığı artırmayabileceği şeklinde yorumlanabilir. $\mathrm{Bu}$ nedenle bilişim güvenliği konusu katılımcıların kullanım süresi yüksek diye göz ardi edilmemelidir.

Tablo 14. Ortalama İnternet Kullanımı Göre Kay-Kare Testi Sonuçları

\begin{tabular}{|c|c|c|c|c|c|c|}
\hline Soru & & $\begin{array}{l}\text { Ortalamanin } \\
\text { Üstü (\%) }\end{array}$ & $\begin{array}{l}\text { Ortalamanin } \\
\text { Alt1 }(\%)\end{array}$ & $\chi^{2}$ & sd & $\mathrm{p}$ \\
\hline \multirow{3}{*}{$\begin{array}{l}\text { S1 - İnternetten alış-veriş } \\
\text { yaparken internetten } \\
\text { ödeme güvenliği hakkın- } \\
\text { da nelere dikkat etmem } \\
\text { gerektiğini bilirim. }\end{array}$} & $\begin{array}{l}\text { Benim için } \\
\text { doğru }\end{array}$ & $\underline{51,0}$ & $\underline{66,1}$ & \multirow{3}{*}{9,52} & \multirow{3}{*}{4} & \multirow{3}{*}{,049 } \\
\hline & Kararsızım & 7,2 & 4,9 & & & \\
\hline & $\begin{array}{l}\text { Benim için } \\
\text { doğru } \\
\text { değil }\end{array}$ & 41,6 & 28,9 & & & \\
\hline \multirow{3}{*}{$\begin{array}{l}\text { S3 - İnternetten alış-veriş } \\
\text { yaparken internetten } \\
\text { ödeme güvenliği hakkın- } \\
\text { da nelere dikkat etmem } \\
\text { gerektiğini bilirim. }\end{array}$} & $\begin{array}{l}\text { Benim için } \\
\text { doğru }\end{array}$ & $\underline{80,7}$ & $\underline{60,0}$ & \multirow{3}{*}{10,00} & \multirow{3}{*}{4} & \multirow{3}{*}{,040 } \\
\hline & $\begin{array}{l}\text { Kararsızım } \\
\text { Benim icin }\end{array}$ & 7,5 & 20,0 & & & \\
\hline & $\begin{array}{l}\text { doğru } \\
\text { değil }\end{array}$ & 11,8 & 20,0 & & & \\
\hline \multirow{3}{*}{$\begin{array}{l}\text { S25 - Bilgisayarımda } \\
\text { (kırılmış) yasa dışı yolla } \\
\text { edinilmiş yazılımlar bu- } \\
\text { lunmaktadır. }\end{array}$} & $\begin{array}{l}\text { Benim için } \\
\text { doğru }\end{array}$ & $\underline{47,4}$ & 28,9 & \multirow{3}{*}{10,10} & \multirow{3}{*}{4} & \multirow{3}{*}{,039 } \\
\hline & Kararsızım & 17,2 & 15,2 & & & \\
\hline & $\begin{array}{l}\text { Benim için } \\
\text { doğru } \\
\text { değil }\end{array}$ & 35,4 & $\underline{55,9}$ & & & \\
\hline \multirow{3}{*}{$\begin{array}{l}\text { S35 - İnternet kaynaklı } \\
\text { tehditler ile ilgili yeterli } \\
\text { bilgiye sahibim. }\end{array}$} & $\begin{array}{l}\text { Benim için } \\
\text { doğru }\end{array}$ & $\underline{59,7}$ & $\underline{40,9}$ & \multirow{3}{*}{12,54} & \multirow{3}{*}{4} & \multirow{3}{*}{,014 } \\
\hline & Kararsızım & 26,5 & 33,3 & & & \\
\hline & $\begin{array}{l}\text { Benim için } \\
\text { doğru } \\
\text { değil }\end{array}$ & 13,8 & 25,8 & & & \\
\hline \multirow{3}{*}{$\begin{array}{l}\text { S44 - Parola güvenliğinin } \\
\text { zayıf, orta, yüksek olma- } \\
\text { sının parolamın güvenli- } \\
\text { ğini nasıl etkilediğini } \\
\text { biliyorum. }\end{array}$} & $\begin{array}{l}\text { Benim için } \\
\text { doğru }\end{array}$ & $\underline{83,0}$ & 66,3 & \multirow{3}{*}{9,91} & \multirow{3}{*}{4} & \multirow{3}{*}{,042 } \\
\hline & Kararsızım & 7,4 & 17,8 & & & \\
\hline & $\begin{array}{l}\text { doğru } \\
\text { değil }\end{array}$ & 9,6 & 15,9 & & & \\
\hline
\end{tabular}

Tablo 14'te sunulan bulgulara göre ortalamanın üzerinde internet kullanan bireylerle ortalamanın altında internet kullanan bireylerin çoğunluğu genellikle güvenlik konularıyla ilgili farkındalık sahibidir. Ancak 25. madde de gruplara göre yanıtların farklılaştığ ${ }_{1}$ önemli bir farklılık görülmemektedir. Bu farklılığa göre ortala- manın üstünde internet kullanan bireyler daha çok yasa dışı (kaçak) yazılım kullandıklarını belirtmişlerdir. $\mathrm{Bu}$ durum daha çok internet kullananların öncelikli olarak etik ve ahlaki kurallarla ilgili bilgilendirilmesi ve farkındalık oluşturulması gerektiğini göstermektedir. Bunun dışında genel olarak ortalamanın üstünde- 
ki grubun bilişim güvenliği farkındalıkları ortalama altı gruba göre daha yüksektir. Bu iki bulgu birlikte dikkate alındığında ortalamanın üstündeki grup için farkındalığın artmasıyla birlikte etik dışı kullanımında artması dikkat çekici önemli bir ikilemi ortaya koymaktadır. Güvenliğe yönelik farkındalık artarken etik farkındalık daha düşük çıkmaktadır.

\subsubsection{Bilişim Güvenliği Eğitimi Alıp Almama Durumuna Göre Kay-Kare Testi Sonuçları}

Bilişim güvenliği eğitimi aldığını belirtenler "Evet", bilişim güvenliği ile ilgili eğitim almadığını belirtenler ise "Hayır" olarak tabloda gösterilmiştir.

Tablo 15. Bilişim Güvenliği Eğitimi Alıp Almama Durumuna Göre Kay-Kare Testi Sonuçları

\begin{tabular}{|c|c|c|c|c|c|c|}
\hline \multicolumn{2}{|l|}{ Soru } & Evet $(\%)$ & Hayır(\%) & $\chi^{2}$ & sd & $\mathrm{p}$ \\
\hline \multirow{3}{*}{$\begin{array}{l}\text { S2 - Farklı sitelere üye olurken } \\
\text { aynı kullanıcı adı ve parolayı } \\
\text { kullanırım. }\end{array}$} & Benim için doğru & 51,3 & 66,8 & \multirow{3}{*}{10,68} & \multirow{3}{*}{4} & \multirow{3}{*}{,030 } \\
\hline & Kararsızım & 0 & 6,9 & & & \\
\hline & $\begin{array}{l}\text { Benim için doğru } \\
\text { değil }\end{array}$ & $\underline{48,7}$ & $\underline{26,3}$ & & & \\
\hline \multirow{3}{*}{$\begin{array}{l}\text { S28 - Parolamı belirli zaman } \\
\text { aralıklarında değiştiririm. }\end{array}$} & Benim için doğru & $\underline{42,5}$ & $\underline{37,6}$ & \multirow{3}{*}{10,67} & \multirow{3}{*}{4} & \multirow{3}{*}{,030 } \\
\hline & \multirow{2}{*}{$\begin{array}{l}\text { Kararsızım } \\
\text { Benim için doğru } \\
\text { değil }\end{array}$} & 12,5 & 20,8 & & & \\
\hline & & 45,0 & 41,6 & & & \\
\hline \multirow{4}{*}{\multicolumn{2}{|c|}{$\begin{array}{l}\text { Tablo } 15 \text { 'te verilen bulgulara göre anlamlı fark- } \\
\text { lılık çıkan madde sayısının azlığı verilen bilişim } \\
\text { güvenliği eğitimlerinin yeteri kadar etkili ol- } \\
\text { madığı göstermektedir. Bu nedenle daha etkili }\end{array}$}} & \multicolumn{5}{|c|}{ Ancak her iki grupta da farkındalık sahibi } \\
\hline & & \multirow{2}{*}{\multicolumn{5}{|c|}{$\begin{array}{l}\text { olmayan önemli düzeyde katılımcı bulunmak- } \\
\text { tadır. }\end{array}$}} \\
\hline & & & & & & \\
\hline & & \multirow{2}{*}{\multicolumn{5}{|c|}{$\begin{array}{l}\text { 3.3.1 "Bir Alış-Veriş Sitesinden Alış-Veriş } \\
\text { Yaparken Sitenin Hangi Özelliklerine Dikkat }\end{array}$}} \\
\hline bir biçimde bu dersin nasıl veri & si gerektiği, & & & & & \\
\hline içerik vb. konularla ilgili yeni & malar yap1- & \multirow{3}{*}{\multicolumn{5}{|c|}{$\begin{array}{l}\text { Edersiniz?" Sorusuna Verilen Yanitların Da- } \\
\text { ğılımı }\end{array}$}} \\
\hline labileceği akla gelmektedir. Eğit & alıp almama & & & & & \\
\hline durumuna göre dağılımın anlar & larak farklı & & & & & \\
\hline çıktığı sorularda eğitim alan gr & In farkinda- & \multirow{2}{*}{\multicolumn{5}{|c|}{$\begin{array}{l}\text { Katılımcıların e-alışverişle ilgili dikkat ettikleri } \\
\text { özellikler Tablo 16'da sunulmuştur. }\end{array}$}} \\
\hline lığ1 olmayanlara göre görece & na yüksektir. & & & & & \\
\hline \multicolumn{7}{|c|}{ Tablo 16. “Bir Alış-Veriş Sitesinden Alış-Veriş Yaparken Sitenin Hangi Özelliklerine Dikkat Edersiniz?” } \\
\hline \multicolumn{7}{|c|}{ Sorusuna Verilen Yanıtların Dağılımı } \\
\hline \multicolumn{4}{|c|}{ Yanitlar } & $\%$ & & $\mathrm{f}$ \\
\hline \multicolumn{4}{|c|}{ Alış-veriş yapacağım sitenin güvenilir olmasına } & 44,02 & & 81 \\
\hline \multicolumn{4}{|c|}{ Alış-veriş yapacağım sitenin kullanılma ve tercih edilme oranı ve tanınmışlığı } & 17,93 & & 33 \\
\hline \multicolumn{4}{|l|}{ Güvenlik sertifikasının olmasına } & 8,69 & & 16 \\
\hline \multicolumn{4}{|l|}{ İnternetten alış-veriş yapmam } & 7,60 & & 14 \\
\hline \multicolumn{4}{|l|}{ Ödeme seçeneklerinin çeşitliliği } & 4,34 & & 8 \\
\hline \multicolumn{4}{|l|}{ Site tasarımının güzel olması } & 4,34 & & 8 \\
\hline \multicolumn{4}{|l|}{ Ürün teslimat süresi ve kalitesi } & 2,71 & & 5 \\
\hline \multicolumn{4}{|l|}{ Ürün kalitesi } & 2,17 & & 4 \\
\hline \multicolumn{4}{|l|}{ Fiyatlar } & 1,63 & & 3 \\
\hline 3 boyutlu güvenlik ( $3 d$ Secure) 1 & lanması & & & 1,08 & & 2 \\
\hline Dekont ve makbuz vermesi & & & & 1,08 & & 2 \\
\hline İçeriğinin zengin olması & & & & 1,08 & & 2 \\
\hline Ürünler hakkında yeterli bilgi v & & & & 1,08 & & 2 \\
\hline
\end{tabular}


Ödeme ekranında ekran klavyesi olması

0,54

0,54

0,54

0,54

1

Site hakkındaki olumlu yorumlar

1

Kullanıcı sayısı

1

Kurumsallığ 1

ceğini göstermektedir. Öğrencilerin alış-veriş

Tablo 16 'da yer alan değerlere göre öğrencilesiteleriyle ilgili bazı özelliklere dikkat ettikleri rin internetten alış-veriş yaparken en çok sitebununla birlikte 3 boyutlu güvenlik ( $3 \mathrm{~d}$ secure), nin güvenilir olmasına ve tercih edilme oranına ekran klavyesi gibi internet alış-verişi için dikkat ettikleri görülmektedir. Bilişim güvenliği ilkelerine göre de bireylerin internetten alı̧sönemli olan teknik konular hakkında yeterli veriş yaparken dikkatli olmaları beklenmektedir. Bununla birlikte katılımcılar alışveriş sitesinin güvenilir olmaya yönelik özelliklerine beklenen düzeyde atıfta bulunmamışlardır. $\mathrm{Bu}$ durum bir kavram olarak "güvenlik" kavramı ile ilgili farkındalık olmasına rağmen, bu kavramı dikkate alıp uygulamada eksikler olabilebilgi sahibi olmadıkları görülmektedir.

\subsection{2 "Parola belirlerken parolanin hangi özellikleri taşımasına dikkat edersiniz?" So- rusuna Verilen Yanıtların Dağılımı}

Katılımcıların parola belirlerken dikkat ettikleri özellikler Tablo 17'de sunulmuştur.

Tablo 17. "Parola belirlerken parolanın hangi özellikleri taşımasına dikkat edersiniz?" Sorusuna Verilen Yanıtların Dağılımı

\begin{tabular}{lcc}
\hline \multicolumn{1}{c}{ Yanıtlar } & $\%$ & $\mathrm{f}$ \\
\hline Farklı kombinasyonlar; sayı, noktalama, harf & 44,26 & 81 \\
Hatırlayabileceğim şeyler & 17,48 & 32 \\
Tahmin edilmesi zor & 15,30 & 28 \\
Güvenli olması & 5,46 & 10 \\
Uzun olması & 4,91 & 9 \\
Güçlü olması & 3,27 & 6 \\
Benim için özel olan şeyler & 2,18 & 4 \\
Büyük küçük harf olması & 1,63 & 3 \\
Noktalama olması & 1,63 & 3 \\
Asal sayı olması & 1,09 & 2 \\
Gizli olması & 1,09 & 2 \\
Doğum tarihi & 1,09 & 2 \\
Sitedeki parola yönergelerine uygun & 0,54 & 1 \\
\hline
\end{tabular}

Bulgulara göre öğrencilerin bilişim güvenliği ilkelerine uygun olan güçlü parola belirleme kriterlerine uygun şekilde farklı kombinasyonları parola belirlerken önemli oranda kullandıkları ve genellikle tahmin edilmesi zor şifreleri tercih etme oranlarının yarıya yakın olduğu görülmektedir. Bilişim güvenliği ilkelerine uygun olmayan doğum tarihi gibi tahmin edilmesi kolay şifreleri tercih etmedikleri görülmektedir. Bununla birlikte öğrencilerin önemli bir kısmı beklenen yanıtı tam olarak belirtmemiştir.

\subsection{3 "Bir yazılıma ihtiyaç duyduğunuzda bunu nasıl temin edersiniz?" Sorusuna Veri- len Yanıtların Dağılımı}

Katılımcıların ihtiyaç duydukları yazılımları nasıl temin ettiklerine ilişkin yantların derlendiği sonuçlar Tablo 18' de sunulmuştur. 
Tablo 18. "Bir yazılıma ihtiyaç duyduğunuzda bunu nasıl temin edersiniz?" Sorusuna Verilen Yanıtların Dağılımı

\begin{tabular}{lcc}
\hline \multicolumn{1}{c}{ Yanıtlar } & $\%$ & $\mathrm{f}$ \\
\hline İnternetten indirerek kullanırım & 64,70 & 88 \\
Arkadaşımdan isterim & 20,58 & 28 \\
Bilgisayar mağazasından satın alıım & 9,55 & 13 \\
Korsan alırım & 2,20 & 3 \\
Bu konuda bilgisi olan birinden yardım alırım & 1,47 & 2 \\
Abimden, erkek kardeşimden alırım & 1,47 & 2 \\
\hline
\end{tabular}

Öğrencilerin genellikle yazılımları internet

kullanarak indirip kullandıkları veya arkadaşlarından isteyerek kullandıkları görülmektedir. Diğer yandan bir mağazaya gidip satın alarak yazılım kullanan öğrencilerin de sayısının oldukça az olduğu görülmektedir. İnternetten indirilen ve arkadaştan alınan yazılımlar akla doğrudan bunların ne kadarının kaçak yazılım olduğu sorusunu akla getirmektedir. Diğer bulgularla birlikte dikkate alındığında kaçak yazılım kullanımının bilişim güvenliği ve bili-

Tablo 19. “Bilişsim güvenliği konusunda bilgi aldığınız bir web sitesi, kurum, kuruluş vb. varsa lütfen adını yazınız." Sorusuna Verilen Yanıtların Dağılımı

\begin{tabular}{|c|c|c|}
\hline Yanitlar & $\%$ & $\mathrm{f}$ \\
\hline Sakarya Üniversitesi & 17,39 & 4 \\
\hline Shiftdelete.net & 17,39 & 4 \\
\hline Donanımhaber.com & 13,04 & 3 \\
\hline Forumlar & 8,69 & 2 \\
\hline Anadolu Üniversitesi & 4,34 & 1 \\
\hline Çizgi Tagem & 4,34 & 1 \\
\hline Vitamin & 4,34 & 1 \\
\hline Chip.net & 4,34 & 1 \\
\hline BTK- Bilgi Teknolojileri ve İletişim Kurumu & 4,34 & 1 \\
\hline Turkhackteam.com & 4,34 & 1 \\
\hline Gezginler.com & 4,34 & 1 \\
\hline Türk Bilişim Derneği & 4,34 & 1 \\
\hline Egm-Emniyet Genel Müdürlüğü & 4,34 & 1 \\
\hline Wardom.org & 4,34 & 1 \\
\hline Arkadaş & 4,34 & 1 \\
\hline
\end{tabular}

Tablo 19 'da sunulan bulgulara bakıldığında bilişim güvenliği ile ilgili öğrencilerin genellikle kullanıcı sayısı yüksek olan forum ve web sitelerinden (shiftdelete.net, donanımhaber.com, Çizgi Tagem vb..) bilgi aldıkları ayrıca üniversitelerden bilgi aldıkları görülmektedir. Bununla birlikte öğrencilerin çok azının bilgi şim etiği ile ilgili en önemli sorunlardan biri olduğu söylenebilir.

3.3.4 "Bilişim güvenliği konusunda bilgi aldığınız bir web sitesi, kurum, kuruluş vb. varsa lütfen adını yazınız." Sorusuna Verilen Yanıtların Dağılımı

Katılımcıların bilişim güvenliği konusunda bilgilenme amaçlı kullandıklarını belirttikleri kaynaklar Tablo 19'da sunulmuştur. almaya yönelik çabasının olduğu ( $\mathrm{f}=2)$ dikkat çekmektedir. Ayrıca öğrencilerin bilişim güvenliği için bilgi aldıklarını söyledikleri bazı sitelerin bilişim güvenliği ile doğrudan ilgili olmaması dikkat çekmektedir. Bu nedenle öğrencilere hem bilişim güvenliği farkındalığ kazandırmaya hem de bilgilerini geliştirip 
güncel kalmalarını sağlayacak geçerli ve güvenilir öğrenme kaynaklarını öğretmek bir ihtiyaç olarak ortaya çıkmışırı. 112 katılımcıdan sadece 24' ünün kendini geliştirmeye yönelik olarak bir adres gösterebilmesi dikkat çekicidir. Bu adreslerden bazıları da amaca uygun değildir. $\mathrm{Bu}$ bulgu katılımcıların bilişim güvenliği konusunda kendilerini geliştirme açısından web sitelerinden ve diğer kaynaklardan beklenen düzeyde yararlanmadıklarını, bu konuda farkındalıklarının düşük olduğunu göstermektedir.

\section{SONUÇ ve ÖNERILER}

Genel olarak sonuçlara bakıldığında öğrencilerin çoğunun bilişim güvenliği konusunda farkındalıklarının olduğu görülmektedir. Alan yazında bu konuda yapılan bazı çalışmalarda bireylerin bilişim güvenliği/bilgi güvenliği bilgi düzeyleri iyi iken (İlkan, İşçioğlu, Egelioğlu ve Doğanalp, 2010) ağırlıklı olarak bilişim güvenliği/bilgi güvenliği farkındalıklarının düşük olduğu gözlenmektedir (Dijle, 2006; Dijle ve Doğan, 2011; Pusey ve Sadera, 2011). Bununla birlikte ele alınan birçok boyut açısından azımsanmayacak sayıda öğrencinin kararsız ya da olumsuz yanıt verdiği durumlar da bulunmaktadır. Örneğin öğrencilerin büyük çoğunluğu parola güvenliği konusunda bilgi sahibi oldukların belirtirken, aynı zamanda farklı sitelerde aynı parolayı ve kullanıcı adını kullandıklarını, başka insanlarla parola ve şifrelerini paylaştıkların da belirtmektedirler. Bu bulgu Bilek (2012), Tekerek ve Tekerek (2013), İlkan, İşçioğlu, Egelioğlu ve Doğanalp (2010) bulguları ile benzerlik göstermektedir. Bununla birlikte internetten alış-verişle ilgili bilgilerinin olduğunu söyleyen \%65'lik gruba karşılık \%37'lik grup sanal klavye kullanmamaktadır. Öğrencilerin \%72'si arkadaşlarına bilgisayarlarını kullandırırken konuk oturum açtıklarını belirtirken \%66'lık bölümü bilgisayarlarında konuk oturumun olmadığını belirtmektedir. Antivirüs, sosyal ağ güvenliği, e-posta ve anlık ileti yazılımları, kablosuz ağ kullanımı, yasal ve etik konular ve kendini geliştirme konularıla ilgili öğrencilerin çoğu belirtilen ifadelere katıldıklarını söylemekle birlikte genellikle \%30 dolaylarında katılımcı kararsız ya da olumsuz yanit vermiştir. Bu bulgular Kruger ve Kearney'in (2006), Agamba ve Keengwe'in (2012) çalışmalarında olduğu gibi bireylerin bilişim güvenliğine yönelik tutumları, davranışları ve bilgileri arasında farklılıklar olduğunu göstermektedir.

Bilişim teknolojileri güvenliği maddelerinin cinsiyete göre farklılaşıp farklılaşmadığı incelendiğinde erkek öğrencilerin kız öğrencilere göre kaynağını ve güvenirliğini bilmedikleri kablosuz ağlara bağlanma konusunda daha çok risk aldıkları görülmüş̧ür. Kınay (2012) ve Topçu'nun (2008) bulgularında da erkeklerin kızlara göre güvenlikle ilgili konularda daha fazla risk aldığı görülmektedir. Ancak Mart'ın (2012) bulgularında cinsiyet açısından bilgi güvenliği farkındalıklarının değişmediği ifade edilmiştir. İlbaş (2009) ise çalışmasında kızların erkeklere oranla bilişim suçlarını suç olarak görme oranlarının genel olarak daha fazla olduğunu ifade etmektedir. Ancak bu çalışmanın sonuçları bilişim güvenliği konusunda kızların görece temkinli olduğunu göstermektedir.

İnternet kullanımı süresine göre bilişim güvenliği maddelerine verilen yanıtlar incelendiğinde ortalamanın üstünde internete bağlanan katılımcıların daha çok korsan yazılım kullandıklarını belirtmiş olmaları dikkat çekici bir sonuçtur. Bilişim teknolojilerinden daha çok yararlanmak daha etik kullanım konusunda bir ilerlemeye neden olmamaktadir. Hatta verilecek eğitimlerde daha çok deneyim sahibi kullanıcılara etik ve kanuni kullanımla ilgili öncelik verilmesi gerektiği söylenebilir. $\mathrm{Bu}$ bulgu Mart'ın (2012) bulgularından farklılaşmaktadır. 
Mart (2012) bilgi güvenliği farkındalığı ile bilgisayar, internet kullanımı arasında bir fark olmadığı belirtilmiştir. Bu çalışmada ise bilgisayar deneyimi arttıkça farkındalığın ve ne yazık ki etik dışı kullanımın arttığı görülmüştür. Diğer yandan alan yazındaki bazı çalışmalarda korsan yazılım kullanım oranının ortayüksek düzeyde olduğunu göstermektedir (Bilek, 2012; Dijle ve Doğan, 2011).

Öğrencilerin sorulara verdikleri yanıtlar bilişim güvenliği ve etikle ilgili bir ders alıp almamaları açısından bir farklılık göstermemektedir. Bu bulgu Tekerek'nin (2012) bulguları ile benzerlik göstermektedir. $\mathrm{Bu}$ nedenle bilişim güvenliği ve etikle ilgili bir ders ihtiyacı açı̆̆a çıkmasıyla birlikte bu dersin etkili olabilmesi için içeriğin nasıl olması gerektiği ile ilgili yapılacak çalışmalara ihtiyaç duyulduğu söylenebilir. Mevcut alınan derslerin önemli bir farkındalık ortaya çıkarmadığı görülmektedir. Bu nedenle farkındalık oluşturmanın ötesinde davranışa dönüşecek etkililikte derslere ihtiyaç duyulduğu söylenebilir.

Internet güvenliğiyle ilgili olarak öğrenciler internetten alış-veriş yaparken dikkat edecekleri birçok özellik belirtmişlerdir. Bununla birlikte güvenli kullanım açısından yeterli düzeyde belirtilmemiş önemli araçların olduğu dikkat çekmektedir. Bu sonuç öğrencilerin internetten alış-verişte güvenlikle ilgili farkındalıkları olduğu diğer taraftan gerekli bilgi ve beceriler açısından zayıf olduklarını akla getirmektedir. Bu sonucu destekleyen bir araştırma sonucu da bireylerin internetten alış-veriş konusunda çekingen davrandığını göstermektedir (Bilek, 2012).

Sonuç olarak öğrencilerin bir kısmı farkındalık sahibi iken önemli bir kısmı bu açıdan deza- vantajlıdır. Katılımcıların bilişim güvenliği konusunda kendilerini hangi kaynaklardan geliştirmeye çalıştıkları sorusuna tatminkâr bir yanıt alınamamıştır. Bu nedenle bilişim güvenliği ile ilgili verilebilecek derslerin yanı sıra bireylerin bilgilerini güncelleyecekleri, kendilerini geliştirecekleri olanaklar sunmaya yönelik araştırmalar yapılması ve önerilerin geliştirilmesi güvenli bilişim teknolojisi kullanımına katkı sağlayacaktır.

Alan yazında yapılan çalışma sonuçlarına göre de bilişim güvenliği farkındalığı kazandırmaya yönelik eğitimlerin verilmesi gerektiği ifade edilmektedir (Bilek, 2012; İlbaş, 2009; Dijle ve Doğan, 2011; Gökmen, 2014). İleride yapılacak araştırmalarda bilişim güvenliği ve bilişim etiği konularında öğretmenlik programında okuyan öğrencilerin farkındalıklarını artırmak ve yeterli düzeyde bilgilendirmek için neler yapılabileceğini belirlemeye yönelik araştırmalar yapılabilir. Bu araştırmalarda öğrencilerin ihtiyaçları ve beklentileri belirlenerek bu konularla ilgili kitaplar, elektronik kitaplar, web siteleri vb. öğretim materyalleri geliştirerek bunların etkililiği incelenebilir. Bu konulara yönelik kurslar, dersler tasarımlanarak bunların etkililiğine yönelik deneysel çalışmalar ve araştırmageliştirme projeleri yapılabilir. Ancak yalnızca bireylere sadece bilgi kazandırmak yerine tutum ve davranış kazandırmaya yönelik etkinliklerin yapılması bu araştırma sonuçlarında ortaya çıkan önemli bulgulardan biri olarak görülmektedir. Bu çalışmaların gerçekleşmesi için, bu sınırlı çalışmada elde edilen bulguların ihtiyaç analizlerine ve geliştirilecek eğitimlere yönelik ipuçları sunması umulmaktadır. 


\section{Kaynakça}

Agamba, J. ve Keengwe, J. (2012). Pre-Service Teachers' Perceptions of Information Assurance and Cyber Security. International Journal of Information and Communication Technology Education, 8(2), 94101.

Avrupa Birliği Siber Suç Sözleşmesi. (t.y.). http://www.coe.int/t/dghl/cooperation/economiccrime/ Source/Cybercrime/TCY/ETS\%20185\%20turkish.pdf

Baykara, M., Daş, R. ve Karadoğan, İ. (2013). Bilggi Güvenliği Sistemlerinde Kullanılan Araçların İncelenmesi. 1st International Symposium on Digital Forensics and Security, Elazığ. http://perweb.firat.edu.tr/personel/yayinlar/fua 721/721 80043.pdf adresinden 27.01.2015 tarihinde erişilmiştir.

Bilek, B.T. (2012). Bilişim Suçları ve Üniversite Lisans Öğrencilerin Biliş̧im Suçlarına Yönelik Görüşleri. Yüksek lisans tezi, Gazi Üniversitesi, Bilişim Enstitüsü, Ankara.

Büyüköztürk, Ş. (2012). Sosyal Bilimler İçin Veri Analizi El Kitabı (17. Baskı). Ankara: PegemA Yayıncılık.

Büyüköztürk, Ş., Kılıç Çakmak, E., Akgün, Ö. E., Karadeniz, Ş. ve Demirel, F. (2012). Bilimsel Araştırma Yöntemleri (11. Baskı). Ankara: PegemA Yayıncılık.

CSI. (2011). Computer Crime \& Security. http://gatton.uky.edu/FACULTY/PAYNE/ACC324/ CSISurvey2010.pdf

Canbek, G. (2005). Klavye Dinleme ve Önleme Sistemleri Analiz, Tasarım ve Geliştirme. Yayınlanmamış Yüksek lisans tezi, Gazi Üniversitesi, Fen Bilimleri Enstitüsü, Ankara.

Canbek, G. ve Sağıroğlu, Ş. (2006). Bilgi, Bilgi Güvenliği ve Süreçleri Üzerine Bir İnceleme. Politeknik Dergisi, 9(3), 165-174.

Cavusoglu, H., Cavusoglu, H. ve Raghunathan, S. (2004). Economics of IT Security Management: Four Improvements to Current Security Practices. Communications of the Association for Information Systems, 14, 65-75.

Çalık, D. ve Çınar, Ö. P. (2009). Geçmişten Günümüze Bilgi Yaklaşımları Bilgi Toplumu ve Internet. 14. Türkiye'de Internet Konferansı Bildirileri, 12-13 Aralık, İstanbul.

Dedeoğlu, G. (2006). Bilişim Toplumu ve Etik Sorunlar. Bursa: Alfa Aktüel Yayınları.

Dijle, H. (2006). Türkiye'de Eğitimli İnsanların Bilişim Suçlarına Yaklaşımı. Yayınlanmamış yüksek lisans tezi, Gazi Üniversitesi, Fen Bilimleri Enstitüsü, Ankara.

Dijle, H. ve Doğan, N. (2011). Türkiye' de Bilişim Suçlarına Eğitimli İnsanların Bakışı. Bilişim Teknolojileri Dergisi, 4(2), 43-53.

Gordon, S. ve Ford, R. On the definition and classification of cybercrime. Journal in Computer Virology, 2, 13-20.

Gordon, L. A. ve Loeb, M. P. (2002). The Economics of Information Security Investment. ACM Transactions on Information and System Security, 5(4), 438-457. 
Gökmen, Ö. F. (2014). Bilgisayar ve Öğretim Teknolojileri Eğitimi Öğretmen Adaylarının Bilişim Güvenliği Ĕ̆itimi Verebilme Yeterliklerinin İncelenmesi. Yayınlanmamış yüksek lisans tezi, Sakarya Üniversitesi, Eğitim Bilimleri Enstitüsü, Sakarya.

İlbaş, Ç. (2009). Bilişim Suçlarının Sosyo-Kültürrel Seviyelere Göre Algı Analizi. Yayınlanmamış Yüksek lisans tezi, Başkent Üniversitesi, Fen Bilimleri Enstitüsü, Ankara.

İlbaş, Ç. ve Köksal, M. A. (2011). Türkiye Bilişim Suçları Raporu: 1990-2011 Temmuz. 2. Uluslararası Bilişim Hukuku Kurultayı Bildiriler Kitabı. İzmir.

İlkan, M., İşçioğlu, E., Egelioğlu, F. ve Doğanalp, A. (2010). Information Security Awareness of Academic Staff Members: An Example of Eastern Mediterranean University School of Computing and Technology. 4. Uluslararası Bilgi Güvenliği ve Kriptoloji Konferansı Bildirileri, Orta Doğu Teknik Üniversitesi, Ankara.

Kınay, H. (2012). Lise Öğrencilerinin Siber Zorbalık Duyarlıh̆̆ının Riskli Davramış, Korumacı Davranış, Suça Maruziyet ve Tehlike Algısı İle İlişkisi ve Çeşitli Değişkenler Açısından İncelenmesi. Yüksek lisans tezi. Sakarya Üniversitesi, Eğitim Bilimler Enstitüsü, Sakarya.

Kritzinger, E. ve Smith, E. (2008). Information Security Management: An Information Security Retrieval and Awareness Model for Industry. Computers \& Security, 27(5-6), 224-231.

Kruger, H. A. ve Kearney, W. D. (2006). A Prototype for Assessing Information Security Awareness. Computers \& Security, 25, 289-296.

Mann, D. ve Sutton, M. (1998). NETCRIME, More Change in the Organization of Thieving. British Journal of Criminology, 38(2), 201-229.

Mart, İ. (2012). Bilişim Kültüründe Bilgi Güvenliğgi Farkındalı̆̆ı. Yüksek lisans tezi. Kahramanmaraş Sütçü İmam Üniversitesi, Fen Bilimleri Enstitüsü, Kahramanmaraş.

Pro-G. (2003). Bilişim Güvenliği. Sürüm 1.1. Proje Bilişim Güvenliği ve Araştırma San. ve Tic. Ltd. Şti. http://www.pro-g.com.tr/whitepapers/bilisim-guvenligi-v1.pdf 02.05. 2014 tarihine erişilmiştir.

Pusey, P. ve Sadera, W. A. (2011). Cyberethics, cybersafety, and cybersecurity: Preservice teacher knowledge, preparedness, and the need for teacher education to make a difference. Journal of Digital Learning in Teacher Education, 28(2), 82-85.

Sağıroğlu, Ş. ve Vural, Y. (2008). Kurumsal Bilgi Güvenliği ve Standartları Üzerine Bir İnceleme. Gazi Üniversitesi Mühendislik-Mimarlık Fakültesi Dergisi, 23(2), 507-522.

Siber. (2013). Siber Suçlarla Mücadele Daire Başkanlı̆̆ı. http://www.siber.pol.tr

Symantec. (2014). Internet Security Threat Report. http://www.symantec.com/content/en/us/ enterprise/other_resources/b-istr_main_report_v19_21291018.en-us.pdf

Şahinaslan, E., Kandemir, R. ve Şahinaslan, Ö. (2009). Bilgi Güvenliği Farkındalık Eğitimi Örneği. XI. Akademik Bilişim Konferansı Bildirileri, Şanlıurfa.

Şahinaslan, E., Kaantürk, A., Şahinaslan, Ö. ve Borandağ, E. (2009). Kurumlarda bilgi güvenliği farkındahı̆ğ, önemi ve oluşturma yöntemleri. XI. Akademik Bilişim Konferansı Bildirileri, Şanlıurfa. 
TCK. (2014).Türk Ceza Kanunu. http://www.mevzuat.gov.tr/MevzuatMetin/1.5.5237.doc

Thompson, M. E. ve Solms V. R. (1998). Information security awareness: educating your users effectively. Information Management \& Computer Security, 6(4), 167-173.

Topcu, Ç. (2008). The Relationship Of Cyberbullying to Empathy, Gender, Traditional Bullying, Internet Use and Adult Monitoring. Yayınlanmamış Yüksek lisans Tezi. Orta Doğu Teknik Üniversitesi Sosyal Bilimler Enstitüsü. Ankara.

Tekerek, M. (2008). Bilgi Güvenliği Yönetimi. KSÜ Fen ve Mühendislik Dergisi, 11(1), 132-137.

Tekerek, M.(2012). Illköğretim ve Lise Öğrencilerinin Bilgi ve Bilgisayar Güvenliği Farkındalı̆̆ı: Kahramanmaraş Örneği. Uluslararası Bilgi Güvenliği ve Kriptoloji Konferans, Ankara.

Tekerek, M. ve Tekerek, A. (2013). A Research on Students' Information Security Awareness. Turkish Journal of Education, 2(3), 61-70.

Wagner, A. E. ve Brooke, C. (2007). Wasting time: The mission impossible with respect to technologyoriented security approaches electronic. Journal of Business Research Methods, 5(2), 117-124.

Whitman, M. E. ve Mattord, H. J. (2012). Principles of Information Security (Fourth Edition). Boston, USA: Course Technology.

Yavuz, H. ve Ulaş, M. (2013). Adli Bilişime konu olan Bilişim Suçları ve Bilgi Güvenliği Farkındalık Tespiti. 1. International Symposium on Digital Forensics and Security Proceding Book. Frat Üniversitesi, Elazı̆g.

Vural, Y. ve Sağıroğlu, Ş. (2008). Kurumsal Bilgi Güvenliği ve Standartları Üzerine Bir İnceleme. Gazi Üniversitesi Mühendislik-Mimarlık Fakültesi Dergisi, 23(2), 507-522. 


\section{Extended Summary}

Information and communication technologies penetrate almost every aspect of life with computers, mobile phones and tablet computers. These technologies provide us with many advantages for a efficient and effective learning. At the same time they have many risks with vulnerabilities and improper unsafe use. Therefore safely and proper use of information and communication technologies (ICT) are vital.

Cybercriminals, hackers and other bad-intended people can try to harm people with using ICT as well. That makes information security an important issue for ICT users. A long with the FATIH project same ICT technologies were provided to teachers and students in most of anatolian high school in Turkey. Therefore it is important to let them gain necessary knowledge and skills in information security. Especially teachers may have an important role for guiding their students to use ICT safely and properly. The purpose of this study is to investigate information security awareness of prospective teachers enrolled in Sakarya University Faculty of Education.

In this context following questions investigated:

1- How is the level of awareness of faculty of education senior students at password security, online shopping, anti-virus and anti-malware software, security updates, social network security, email and instant message security, wireless networks, legal and ethical issues, improving and updating their knowledge.

2- Is awareness level of information security significantly change according to; gender, computer and internet experience by year and whether taking an education or course about information security or not.

3- What are the views of participants about considering security of shopping online, deciding a password, obtaining or buying software and how do they update their ICT security information?

This study is conducted in cross-sectional survey model with 212 senior students from Elementary Mathematics Education (39), Computer and Instructional Technologies Education (64), Turkish Language Education (74), Mentally Handicapped Education departments (35). Data was collected through "Information Security Questionnaire" developed by authors. Questionnaire includes 48 number of 5likert-type and 18 number of usage, demographics questions. Data was analyzed by using Chi-Squire, frequencies, descriptive statics via SPSS.

According to the results, there is not little number of students having low level awareness about ICT security. This result shows important needs of education about ICT security for participants. On the other hand there are some contradictory results. Although most of the participants report that they know how to create a strong password, they admit they tell their passwords to friends and use same passwords. This result show that the participants are at high level of awareness about some issues but not well enough in others.

$65 \%$ of the participants report that they know how to shop online, but $37 \%$ of them admit they don't use secure virtual keyboard. Therefore it takes notice that there are important differences in their reports and usage patterns.

In addition to these results female participant are more cautious than males in some security issues. There is not a significant effect of whether taking a course or a education about information security on participants' responses. This means existing courses are not enough for improving significantly change ICT security awareness and usage patterns. It is suggested to design and implement proper and efficient courses about ICT security for prospective teachers. New studies and research projects are needed to improve ICT security awareness, knowledge and skills of prospective teachers. 